\title{
Potential Shade Structures to Improve Graft-Take and the Growth of Soft -Wood Grafts in Cashew (Anacardium occidentale L.)
}

\author{
Satya SS Narina ${ }^{1 *}$, C Ravi Sankar ${ }^{1}$, Hanumantha Rao GV² and M Laxmi \\ Narayan Reddy ${ }^{3}$ \\ ${ }^{1}$ Department of Horticulture, Agricultural College, Bapatla, India \\ ${ }^{2}$ Department of Plant Physiology, Agricultural College, Bapatla, India \\ ${ }^{3}$ Agricultural Research Station, Bapatla, India \\ *Corresponding Author: Satya SS Narina, Department of Horticulture, Agricultural \\ College, Bapatla, India.
}

DOI: 10.31080/ASNH.2020.04.0629
Received: January 17, 2020

Published: January 29, 2020

(C) All rights are reserved by Satya SS Narina., et al.

\begin{abstract}
Cashew is the best income earning plantation crop of south eastern tropical regions in the coastal sandy and alluvial soils. Cashew has received adequate research attention in vegetative propagation, but its improvement for higher yields and high-density planting is still a necessity. To reach this milestone in research, an attempt was made twice experimentally at the cashew research station in Bapatla to identify the best method out of two techniques of soft-wood grafting (SWG) developed with different aged rootstocks of BPP-5 and scionsticks of BPP-6 cultivar under eight shade providing structures with a control in light, temperature and relative humidity for a period of seven months in three replications. The results revealed that a lesser aged (35-45 days old) rootstock with less number (only two) of leaves was prolific to give sufficient foliage after successful graft union using SWG under HDPS (high density polythene sheet) shade nets and low-cost structure like trench and a structure with coconut fronds. Significant differences were observed for all the growth traits except for height. These structures were providing a partial shade of 10 to 50 percent with success in sprouting (65.58\%) and graft-take (50.1-59.81\%) in a short period of time. All these structures with high success percentage provided more than 80 percent photosynthetically active radiation to the SWGs. Major achievement is attributed to identification of (1) reduced age of rootstock at 35 days for Bapatla method and 45 days for Puttur method (2) a prior requirement of shade for 20 days (3) a low-cost structure like shallow trench was suitable for microclimate required for successful SWG in cashew in our region. In this study, the rootstock BPP-5 was potential for producing more than 80 percent of successful SWGs made during the study period. For the establishment of new orchards with high density planting, genetically competent, prolific scion cultivars with high yield potential like BPP-6 were essential, though identification of its dwarfing rootstock is still a lacuna in cashew research.

Keywords: Low Cost Methods; Trench; Vegetative Propagation; Dwarfing Rootstock; High-Density Planting
\end{abstract}

\section{Abbreviations}

CRS: Cashew Research Station; HDPS: High density polyethylene netted sheet used as shade net also called as high-density polythene shade nets and were available in 25, 50 and 75 percent shade; HD: High Density; M1 to M7: Month 1 (September) to Month 7 (March); SWGs: Soft-Wood Grafts; SWG: Soft Wood Grafting; PAR: Photosynthetically Active Radiation; SS1 to SS7: Shade Structure 1 to Shade Structure 7.

\section{Introduction}

Cashew is cultivated in 6,34,970 ha producing $4,17,830$ tons of nuts in 1995-96. Due to increase in demands of processing units and exports, import of raw cashew nuts has been increasing since 1970s. Though lots of hybrids, clonal cultivars of high yielding varieties were developed at Cashew Research Station (CRS), Bapatla and other research locations of India there is still an apparent need for qualitative and quantitative increases in nut yields.
Nursery production of softwood grafts (SWG) with quality, survival and better orchard establishment capacity is necessary. The major factors affecting the quality, mortality and establishment of SWGs were genetic, mainly genotype of scion and rootstock as well as climatic factors. Climatic factors include light, temperature, rainfall and humidity among which light helps to trigger the photosynthetic activity and for nourishment of growth in grafts. Again, the rate of photosynthesis varies with percentage of available photosynthetically active radiation (PAR). The genetic factors are highly specific to cultivar that might boost the quality of growth under positive conditions of growth factors including PAR.

Establishment of new cashew orchards with proven elite planting material is the current need for improvement of yield, quality of nuts, to meet demands of imports, exports and sustainability in our nation. The graft-take and growth were highly dependent on potential rootstocks adopted for SWG and local weather conditions 
congenial for improving the successful union of scion and rootstock after grafting. Previous studies on SWG in cashew, mango, tamarind and other fruit crops revealed a diverse percentage of success under various geographical regions in India [1-3].

In Andhra Pradesh, CRS at Bapatla is the only place where research on vegetative propagation in cashew has been conducted since 1900s. Sufficient progress made until the discovery of new and modified technique of epicotyl grafting named as SWG [4] and was also identified as easier, cheaper, viable and quick multiplication of high yielding cashew cultivars $[4,5]$. The SWG was practiced on rootstocks of one-month age to one year old depending on the purpose of rejuvenating old trees [6,7], for high graft take and success percentages [8] to multiply new cultivars in large scale [9] for transplanting in a new orchard. The SWG was practiced successfully in fruit crops like apple, cashew, citrus, guava, jack fruit, jujube, mango, pear, peach, pecan-nut and sapota.

A successful graft union occurs in four steps 1) formation of a necrotic layer on the cut surface of each graft partner (scion and rootstock), 2) Parenchymatous tissue divides to form callus cells that fill the space between the graft partners and form an initial cohesion with cell wall materials, 3) The vascular cambium develops across the graft union linking the two partners when in close contact, 4) secondary xylem and phloem re-differentiate across the graft union forming adequate vascular continuity to support plant growth. Hormones such as auxin and cytokinin affect callus formation and abscicic acid (ABA), Ethylene and gibberellic acid (GA) inhibitors increase wood formation and density that improves graft union strength [10]. Thus, grafting is an important event in cultivation of fruit crops including grapevine where rootstocks provide resistance to soil borne pests and diseases and improve tolerance to stresses [11].

The factors that benefit success of this SWG include but not limited to weather, age of the rootstock and number of leaves retained on the rootstock, rootstock cultivar, scion length, scion age, and precuring of the scion stick, shade provided during and after graft preparation [5]. Success in sprouting of scion sticks and survival of grafts was more in June-July to August months and sprouting was observed within a very short period of time in days ranging from 14.33 to 20.66 days in mango [12], 23.3 days in cashew [13] while it took 28 days when grafted from October to December months in Mango [14].

Afternoon relative humidity and higher monthly mean minimum temperatures coupled with high number of rainy days per month are necessary at the time of grafting in mango [15-17], cashew $[18,19]$ and in sapota [20] for rapid callus formation leading to speedy healing of the graft union as well as higher growth of scion shoot and leaf. The success of cashew graft-take and better growth with maximum graft height, leaf area was recorded in $\mathrm{Au}$ gust and September months when the climate was hot and humid while the least success with few leaves was observed in November and December [21].

Number of days took for scion bud sprouting were very minimum (12 to 24 days) when grafts were placed in glasshouse and partial shade with a maximum sprouting percentage of 95.3 when placed in a chamber. The percentage of sprouting was quick with a pair of leaves on the rootstock in mango [22]. In mango, spring and summer grafting produced more rapid growth while late monsoon, prewinter and winter periods produced only moderate to poor vegetative growth [23].

Shade structure "humid chamber" gave the highest percentage of rooting of cashew cuttings [24]. In a sixty-day period, the grafted plants grown in full sun with wind breaks were 47 percent larger and produced more luxuriant foliage compared to those kept in 60 percent shade [25]. While 50 percent and 75 percent shade produced longer shoots and larger leaf area [26], contrarily a reduced growth when shade was increased to more than 50 percent [27]. In citrus seedling, better growth was reported when shade was provided with a black net and transparent $0.22 \mathrm{~mm}$ plastic film [28]. When compared, cleft grafting gave high percent success under shade and produced strong trees [29].

The SWG or grafting alone is more promising and gaining popularity because of benefits of tolerance to cold, salinity, drought, and heavy metal toxicity and soilborne pathogens, due to the resistance found in the rootstocks such as BPP-5 in cashew. Many aspects related to rootstock/scion interactions are poorly understood, which can cause loss of fruit quality, reduced production, shorter postharvest time, and, most commonly, incompatibility between rootstock and scion. Our BPP-5 rootstock and BPP-6 scion were highly compatible and proven successful in cashew. Therefore, the present investigation was carried out twice to study the two methods of softwood grafting using two factors with treatments of shade provided by eight shade structures in a seven-month period during 1996-97 at CRS, Bapatla in Andhra Pradesh. The objective of the research investigation is to find out the best shade structure for producing successful softwood grafts in Bapatla.

\section{Materials and Methods}

The CRS in Bapatla is situated at an altitude of $5.49 \mathrm{~m}$ above msl with $80^{\circ} 28^{\prime}$ eastern longitude and $15^{\circ} 54^{\prime}$ Northern latitude. The experiment was conducted twice during 1996-97 in a factorial design with three replications, two main treatments of methods SWG technique (Bapatla and Puttur). Plate 1 shows the over view of the experimental nursery under open conditions as well as the grafts that were moved to open sun light conditions after 20 days of shade treatment under all shade structures. The two factors we tested to know the influence of shade for successful graft-take were i) Month of grafting include seven months from September (M1) to March (M7) during 1996-97 ii) Shade include eight treatments in percent- 
ages of $0,10-15,12.5-20,25,50,75,100$, and diffused shade). The weekly mean meteorological data collected during experimental period at meteorological observatory of Agricultural College Farm in Bapatla was presented in table 1.

The potting mixture was prepared by mixing red earth, farm yard manure and sand in equal proportions and admixtured with single superphosphate at the rate of $5 \mathrm{~g}$ per $1 \mathrm{~kg}$ of potting mixture and filled in $25 \times 15 \mathrm{~cm}, 250$ guage polythene bags. The rootstocks were raised from matured, well filled seeds weighing $25 \mathrm{~g}$ each from cultivar BPP-5 (Plate 2). The method of SWG technique

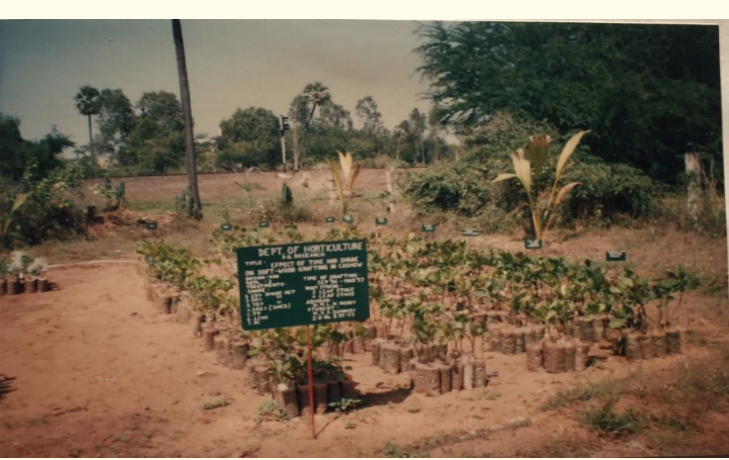

Plate 1: Over all view of the experiments at cashew nursery.

Table 1: Mean weekly meteorological data during the crop period from 3 - 9 - 96 to 10 - 6 - 97.

\begin{tabular}{|c|c|c|c|c|c|}
\hline Standard week & Dates and Month & $\begin{array}{c}\text { Mean temperature } \\
\text { Maximum }\left({ }^{\circ} \mathrm{C}\right)\end{array}$ & $\begin{array}{c}\text { Mean temperature } \\
\text { Minimum }\left({ }^{\circ} \mathrm{C}\right)\end{array}$ & $\begin{array}{l}\text { Mean relative } \\
\text { humidity (\%) }\end{array}$ & Rainfall (mm) \\
\hline 36 & $3 / 9 / 96-9 / 9 / 96$ & 30.80 & 24.80 & 84.70 & 101.50 \\
\hline 37 & $10 / 9 / 96-16 / 9 / 96$ & 32.60 & 24.80 & 78.60 & 26.00 \\
\hline 38 & $17 / 9 / 96-23 / 9 / 96$ & 33.95 & 25.40 & 74.00 & 11.40 \\
\hline 39 & $24 / 9 / 96-30 / 9 / 96$ & 34.00 & 26.10 & 79.50 & 13.90 \\
\hline 40 & $1 / 10 / 96-7 / 10 / 96$ & 31.60 & 25.20 & 79.00 & 99.40 \\
\hline 41 & $8 / 10 / 96-14 / 10 / 96$ & 30.20 & 24.20 & 92.10 & 41.20 \\
\hline 42 & $15 / 10 / 96-21 / 10 / 96$ & 29.30 & 23.30 & 90.60 & 264.10 \\
\hline 43 & $22 / 10 / 96-28 / 10 / 96$ & 30.20 & 24.20 & 83.80 & 10.70 \\
\hline 44 & $29 / 10 / 96-4 / 11 / 96$ & 31.80 & 22.20 & 76.90 & 0.00 \\
\hline 45 & $5 / 11 / 96-11 / 11 / 96$ & 31.10 & 22.40 & 78.00 & 15.80 \\
\hline 46 & $12 / 11 / 96-18 / 11 / 96$ & 31.30 & 21.50 & 86.00 & 2.80 \\
\hline 47 & $19 / 11 / 96-25 / 11 / 96$ & 29.10 & 20.80 & 81.00 & 52.00 \\
\hline 48 & $26 / 11 / 96-2 / 12 / 96$ & 29.30 & 17.20 & 76.00 & 0.00 \\
\hline 49 & $3 / 12 / 96-9 / 12 / 96$ & 27.30 & 20.00 & 78.50 & 15.00 \\
\hline 50 & $10 / 12 / 96-16 / 12 / 96$ & 28.80 & 20.20 & 78.20 & 4.40 \\
\hline 51 & $17 / 12 / 96-23 / 12 / 96$ & 28.60 & 18.20 & 81.60 & 0.00 \\
\hline 52 & $24 / 12 / 96-31 / 12 / 96$ & 28.80 & 16.20 & 77.10 & 0.00 \\
\hline 1 & $1 / 1 / 97-7 / 1 / 97$ & 28.60 & 14.80 & 71.80 & 0.00 \\
\hline 2 & $8 / 1 / 97-14 / 1 / 97$ & 26.90 & 18.60 & 85.60 & 22.30 \\
\hline 3 & $15 / 1 / 97-21 / 1 / 97$ & 28.50 & 18.50 & 74.90 & 0.00 \\
\hline 4 & $22 / 1 / 97-28 / 1 / 97$ & 29.00 & 16.20 & 73.80 & 0.00 \\
\hline 5 & $29 / 1 / 97-4 / 2 / 97$ & 28.70 & 16.70 & 81.10 & 0.00 \\
\hline 6 & $5 / 2 / 97-11 / 2 / 97$ & 29.40 & 19.70 & 82.80 & 0.00 \\
\hline 7 & $12 / 2 / 97-18 / 2 / 97$ & 31.40 & 17.00 & 78.60 & 0.00 \\
\hline 8 & $19 / 2 / 97-25 / 2 / 97$ & 30.50 & 19.80 & 80.80 & 0.00 \\
\hline 9 & $26 / 2 / 97-4 / 3 / 97$ & 31.00 & 18.10 & 75.20 & 0.00 \\
\hline 10 & $5 / 3 / 97-11 / 3 / 97$ & 32.20 & 17.40 & 76.40 & 0.00 \\
\hline 11 & $12 / 3 / 97-18 / 3 / 97$ & 32.30 & 21.90 & 81.30 & 0.00 \\
\hline 12 & $19 / 3 / 97-25 / 3 / 97$ & 34.70 & 24.40 & 79.00 & 0.00 \\
\hline 13 & $26 / 3 / 97-1 / 4 / 97$ & 32.10 & 23.10 & 72.20 & 0.00 \\
\hline 14 & $2 / 4 / 97-8 / 4 / 97$ & 31.10 & 23.50 & 74.60 & 99.30 \\
\hline 15 & $9 / 4 / 97-15 / 4 / 97$ & 32.70 & 24.60 & 79.40 & 0.90 \\
\hline 16 & $16 / 4 / 97-22 / 4 / 97$ & 32.70 & 23.30 & 70.60 & 0.10 \\
\hline 17 & $23 / 4 / 97-29 / 4 / 97$ & 32.50 & 23.40 & 70.80 & 0.00 \\
\hline 18 & $30 / 4 / 97-7 / 5 / 97$ & 33.60 & 24.30 & 71.10 & 8.00 \\
\hline 19 & $8 / 5 / 97-14 / 5 / 97$ & 33.60 & 25.60 & 73.20 & 0.00 \\
\hline 20 & $15 / 5 / 97-21 / 5 / 97$ & 38.00 & 27.30 & 61.30 & 0.20 \\
\hline 21 & $22 / 5 / 97-28 / 5 / 97$ & 40.80 & 28.70 & 53.40 & 1.60 \\
\hline 22 & $29 / 5 / 97-4 / 6 / 97$ & 44.10 & 28.30 & 23.60 & 0.00 \\
\hline 23 & $5 / 6 / 97-11 / 6 / 97$ & 40.60 & 27.50 & 59.80 & 1.30 \\
\hline \multicolumn{2}{|r|}{ Total } & 1273.74 & 1046.73 & 3032.78 & 791.89 \\
\hline \multicolumn{2}{|r|}{ Mean } & 32.84 & 26.17 & 75.82 & 19.80 \\
\hline
\end{tabular}


include (a) retaining two leaves on 30 days old rootstock and (b) retaining four leaves on 45 days old rootstock while grafting on to a scion bud stick from vigorously growing cashew cultivar BPP-6. We slightly modified previous methods recommended for commercial propagation of cashew using SWG methodology suggested at (a) Bapatla [4] and (b) Puttur [22] locations by reducing number of days of the rootstock seedlings to prepare SWGs [30-32].

The precuring of apical scion bud shoots from terminal branches of cultivar BPP- 6 was done 10 days prior to the collection of scion sticks by clipping off leaf blades and leaving petioles. The precured scion-sticks of a pencil size, brown colored round shaped and measuring about $10 \mathrm{~cm}$ length and $2-2.5 \mathrm{~cm}$ girth were separated from mother tree on the day of SWG (10 days after defoliation). These sticks were kept in polythene bags with water to avoid dessication until used for SWG in the presented research study [33,34].

The thirty- and forty-five days old rootstocks were prepared by giving transverse cut to the seedling at a height of $10-15 \mathrm{~cm}$ and $15-20 \mathrm{~cm}$ from the base retaining 2 and 4 leaves respectively for Bapatla and Puttur methods of SWG. A cleft of 4- $5 \mathrm{~cm}$ deep was made in the middle of the decapitated stem by giving longitudinal cut. The scions sticks of same thickness were chosen to mend the cut end into a wedge shape of 4-5 cm length by chopping off the bark and little portion of wood from two opposite sides to retain a thin slice of wood along with bark to fit exactly when inserted into the cleft made in the respective rootstocks. After the wedge of scion inserted into the cleft by matching the cambial layers of both scion and rootstock, the graft joint is secured firmly wrapping with $2.5 \mathrm{~cm}$ wide and $30 \mathrm{~cm}$ long polythene trip of 100 guage thickness. The scion portion of the grafted plant is covered with 100 guage thick HD polythene bag of $15 \mathrm{~cm} \times 10 \mathrm{~cm} \times 100 \mathrm{~cm}$ size to prevent dessication of scion sticks and maintain humidity inside the enclosed space. Plates 2, 3 and 4 represent the methodologies of two techniques used for SWG in our research investigation.

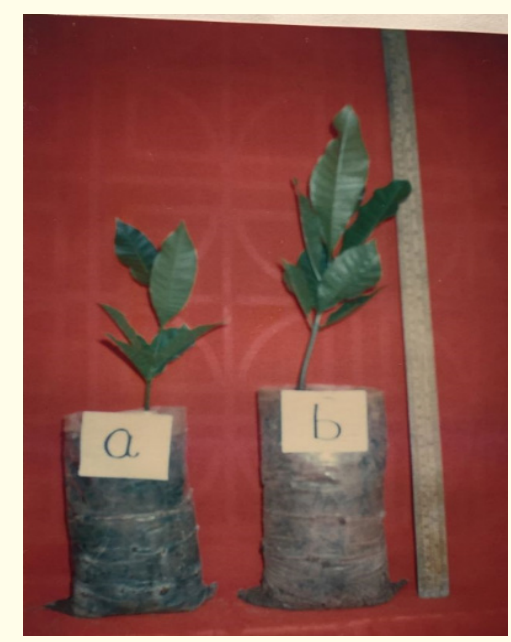

Plate 2: Seedlings ready to use as rootstocks for softwood grafting.

a. In Bapatla Technique, b. In Puttur Technique

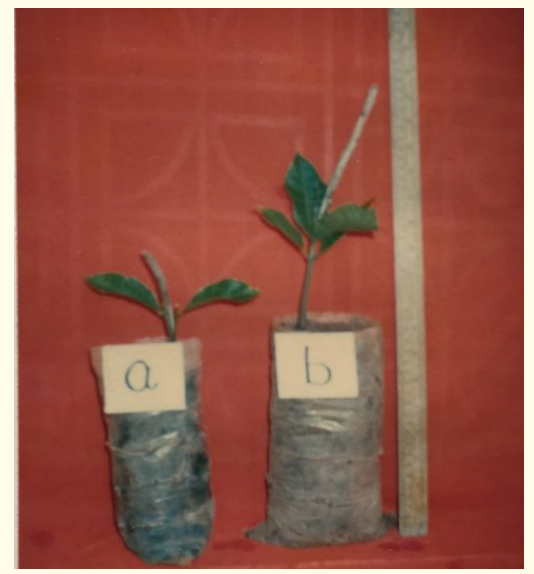

Plate 3: Scion inserted into the cleft matching the cambial regions. a. In Bapatla Technique, b. In Puttur Technique

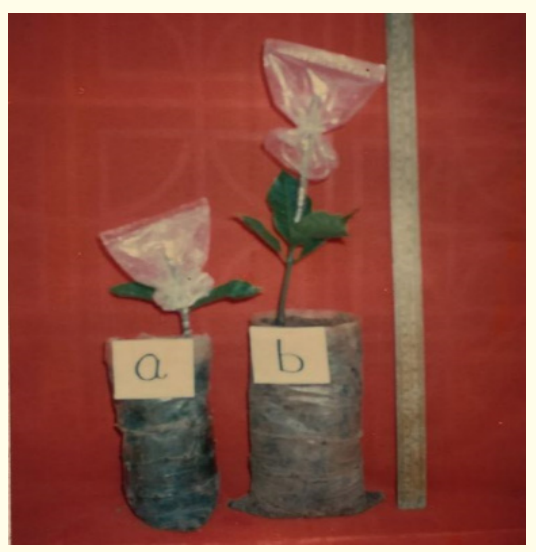

Plate 4: Scion grafted on the rootstock closely fastened and graft covered with polythene cover.

a. In Bapatla Technique, b. In Puttur Technique

The factor "shade" includes seven shade structures (SS1 to SS7) and the eighth treatment was without any structure to provide shade and the prepared grafts were left in the open air under natural climate and weather conditions from September (M1) to March (M7). A black colored high density polythene shade nets or high density polyethylene shade nets (HDPS) that were provided with very small holes of varying sizes to penetrate light and provide shades of different grade namely (i) SS1 to provide 25 percent shade (ii) SS2 to provide 50 percent shade (iii) SS3 to provide 75 percent shade iv) SS4 to provide 100 percent shade. The light intensities were maintained by digital lux meter. In SS4 treatment, the prepared grafts were kept inside a graft-shed where complete shade of 100 percent provided. Plates 5, 6 and 7 display the HDPS shade nets of 25,50 and 75 percent shade respectively.

In addition, shade structures that were most common in Krishna-Godavari Zone (SS5, SS6, and SS7) were also included in the study to compare and provide low cost structure and to eliminate any unnecessary expenditure for nursery graft production. These include (v) A trench with partial shade (SS5): This structure 


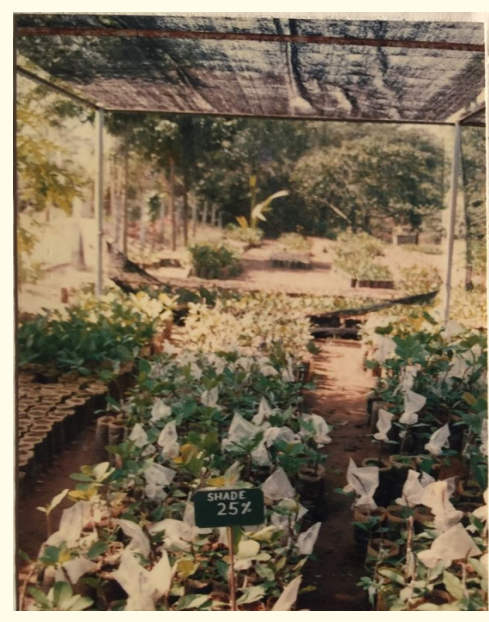

Plate 5: Grafts treated with 25 percent shade under HDPS net-structure (SS1).

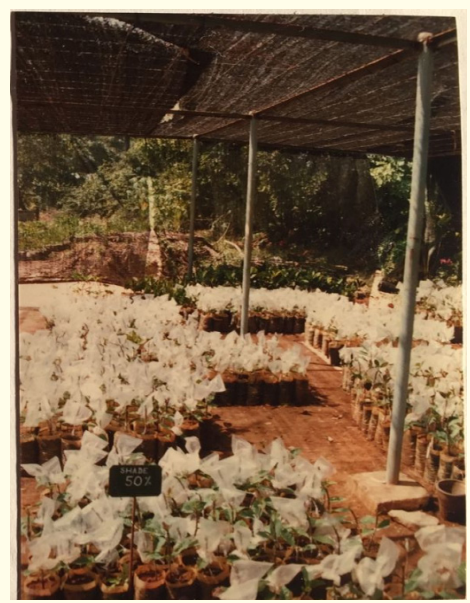

Plate 6: Grafts treated with 50 percent shade under HDPS net-structure (SS2).

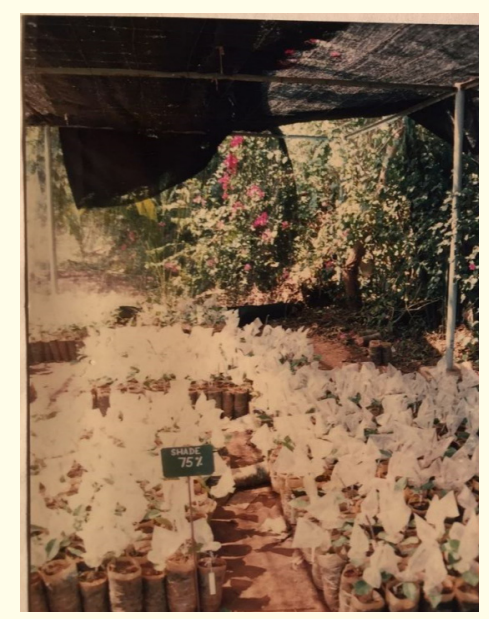

Plate 7: Grafts treated with 75 percent shade under HDPS net-structure (SS3).

was prepared by digging a shallow trench ( $3 \mathrm{~m} \times 1 \mathrm{~m} \times 0.6 \mathrm{~m}$ size $)$ in the ground to fit all the three replications of two main treatments and two experiments. A thick blue polythene sheet of 250 gauge was used to cover the trench and it was opened only during time of irrigation, twice daily (Plate 8). The data was collected only during these specified timings without disturbing the structure and microclimate inside the trench. In trench the relative humidity was maintained between 88 and 92 percent while the shade was maintained between 12.5 and 20 percent. This structure "Trench" (SS5) was dug in the ground with a facility to provide constant temperature and relative humidity which was measured with Pscychrometer. The psychrometer is a hygrometer consisting of a wet-bulb and a dry-bulb thermometer, the difference in the two thermometer readings being used to determine atmospheric humidity.

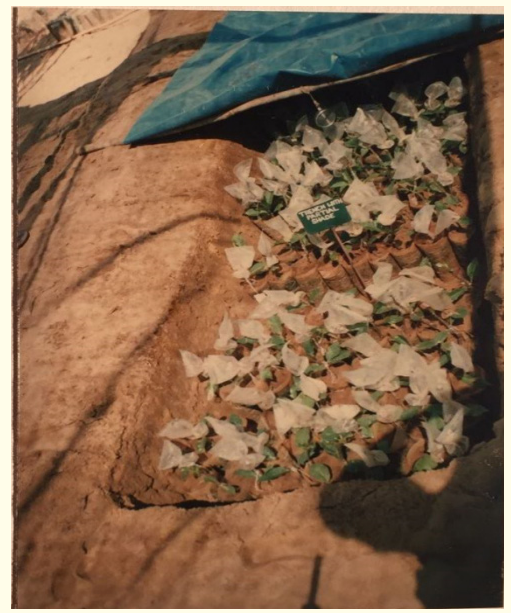

Plate 8: Grafts treated with partial shade inside trench (SS5).

Partial shade with coconut fronds (SS6)

The structure providing partial shade under coconut leaves (SS6) was constructed by erecting a pandal and covered with dried coconut fronds collected from local coconut (Cocos nucifera) trees. This structure was observed providing shade ranging from 10 to 15 percent (Plate 10). In some areas, use of toddy palm (Phoenix dactylifera) leaves was seen, but we preferred to use coconut fronds due to the increased per cent of light and optimum shade provision by coconut leaves compared to palmyra leaves.

\section{Low cost humid chamber (SS7)}

This is a cabinet like portable structure with dimensions $3.6 \mathrm{~m} \mathrm{x}$ $100 \mathrm{~m} \times 0.75 \mathrm{~m}$ ) and was covered with 250-gauge polythene sheet on all sides (Plate 9). In both trench and low- cost humid chamber, only diffused light is allowed to pass through. (viii) No shade (SS8). In SS8, grafts were kept on the ground in the open air without any shade and with provision of 100 percent sun light. The images of the shade treatments were provided for reference and understanding the construction and design (Plate 5 to 10).

All the treatments in two experiments, three replications, received same level of irrigation scheduled twice daily in the morning and evening manually using a sprinkler hose as well as other nursery management practices as necessary. The prepared SWGs of BPP- 5 as rootstock and vigorously growing BPP- 6 as scion material using 2 methods of SWG technique were not moved after imposing treatments of shade until 20 DAG. Five grafts were chosen randomly as samples to collect the data from all the experimental 


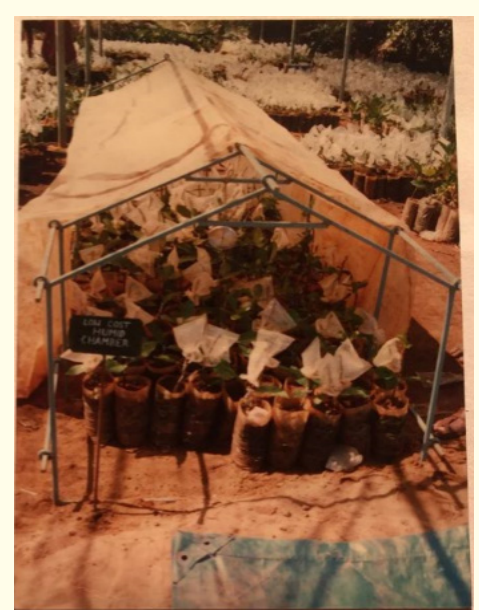

Plate 9: Grafts treated with complete shade in low cost humid chamber (SS7).

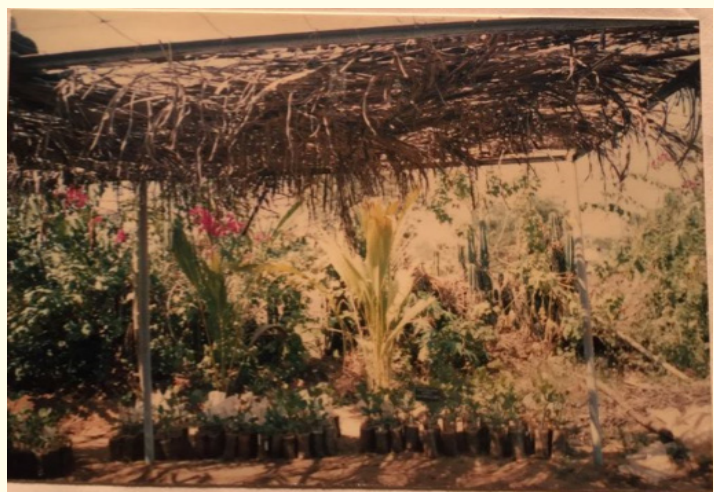

Plate 10: Grafts treated with partial shade under coconut fronds (SS6).

treatments and replications. These five sample data plants were tagged for recording data on the growth parameters like number of leaves, graft height and total leaf area. The percent sprouting, success rate or mortality percentage were also recorded for every treatment plot at regular intervals as explained below.

\section{Description of the variables measured}

- Number of scion-sticks sprouted: The grafts show the sign of growth with terminal bud sprouting and producing small leaves. The grafts sprouted per plot of 25 grafts were counted and recorded at 15, 30 and 45 days after grafting and expressed as percentage.

- Percentage of successful grafts: This is also termed as graft-take and was noted at monthly intervals till 90 days after grafting and expressed in percentage.

- Mortality rate: The total number of sprouts failed to sprout and dried were recorded at monthly intervals till 90 days after grafting and expressed as percentage.

- Graft height: The height of the graft was measured from the collar region of the rootstock to the tip (terminal bud) of the grafted scion at monthly intervals till 90 days after grafting.
- Number of leaves: Total number of fully emerged leaves were counted and recorded at monthly intervals till 90 days after grafting.

- Leaf area: Fifty leaves of different sizes were separated from grafted plants and leaf area was recorded by a digital leaf area meter calibrated correctly. The maximum length and breadth of individual leaves were taken from each graft and their product were obtained (LXB) to have the apparent leaf area. The leaf area was measured in square centimeters as suggested [35].

Actual leaf area, $\mathrm{A}=(\mathrm{LXB}) \mathrm{K}$, where $\mathrm{K}$ is the leaf area constant equal to 0.75 .

From the above equation the value for $\mathrm{K}$ was estimated by dividing actual leaf area with apparent leaf area.

For the selected five grafts in every treated plot, the total leaf area per each graft was obtained using $\mathrm{K}$ value and by measuring the length and breadth of individual leaves. Then the total mean leaf area per graft was calculated.

The data collected from observations made at 15, 30, 45, 60 and 90 DAG for the respective traits were tabulated after calculating means of samples, replications and treatments. The data on these parameters was analysed statistically by the method of analysis of variance procedures outlined [36]. The statistical significance, and critical difference (CD) were worked out based on $\mathrm{F}$ test values at 5 percent level of significance. The analysis did not include any data on SS8 treatment and hence the presented tables are without the data on eighth shade treatment.

\section{Results and Discussion}

The weekly mean minimum and mean maximum temperatures during the period of investigation ranged from $14.8^{\circ} \mathrm{C}$ to $28.7^{\circ} \mathrm{C}$ and $27.3^{\circ} \mathrm{C}$ to $44.1^{\circ} \mathrm{C}$ respectively. The weekly mean relative humidity was ranging from 29.6 to 92.1 percent and total rainfall received during the period of investigation was $791.89 \mathrm{~mm}$ (Table 1). The data presented here is the averages obtained from five samples, three replications in seven months under seven different shade treatments.

Influence of shade on sprouting and production of successful grafts

The analysis of variance revealed significant treatment differences for all the traits studied between two methods of SWG employed as well as among shade structures. The summary of comparisons on success percentages was provided (Table 2) indicating high success in Bapatla (59.62\%) method followed by Puttur (56.23\%) method by $30 \mathrm{DAG}$ and a stability in success after $30 \mathrm{DAG}$ with a reduction of less than $10 \%$ in both techniques. The average per cent of successful grafts were more in Bapatla (52.54) compared to Puttur (49.31). Further, the overall success percentage increased due to shade treatment during various months of different 
climate and rainfall in Bapatla. The reason for this is early success in healing of graft union in both techniques due to shade treatment provided for first 20 days and were discussed in detail below.
The average data in percentage for sprouting was observed with extreme variation from 15 to 45DAG under all shade treatments and was presented in tables 3 and 4 for Bapatla and Puttur methods. The treatments and interactions showed significant variation

Table 2: Comparison of Bapatla and Puttur techniques of softwood grafting in cashew at 30, 60 and 90 days after grafting (DAG) for average success due to shade treatments in percentage.

\begin{tabular}{|l|c|c|c|c|c|c|c|c|}
\hline \multirow{2}{*}{ Treatment } & \multicolumn{4}{|c|}{$\begin{array}{c}\text { Success grafts (\%) obtained with Bapatla method } \\
\text { on the following days after grafting }\end{array}$} & \multicolumn{3}{c|}{$\begin{array}{c}\text { Success grafts (\%) obtained with Puttur method } \\
\text { on the following days after grafting }\end{array}$} \\
\cline { 2 - 9 } & $\mathbf{3 0}$ & $\mathbf{6 0}$ & $\mathbf{9 0}$ & $\mathbf{M e a n}$ & $\mathbf{3 0}$ & $\mathbf{6 0}$ & $\mathbf{9 0}$ & $\mathbf{9 0}$ \\
\hline Shade (SS) & 58.90 & 50.10 & 47.89 & 52.30 & 56.29 & 46.03 & 45.67 & 49.33 \\
\hline Month (M) & 60.33 & 50.10 & 47.89 & 52.77 & 56.16 & 46.03 & 45.67 & 49.29 \\
\hline Grandmean & 59.62 & 50.10 & 47.89 & 52.54 & 56.23 & 46.03 & 45.67 & 49.31 \\
\hline
\end{tabular}

Note: SS represents mean data obtained from softwood grafts under various shade structures

excluding 100 percent shade and no shade during the experimental period.

Table 3: Comparison of shade structures and two techniques of soft-wood grafting in terms of total percent of scion-sticks sprouted by 45 days after grafting (DAG) and successful cashew grafts produced by 90 DAG.

\begin{tabular}{|l|c|c|c|c|c|c|}
\hline \multirow{2}{*}{$\begin{array}{c}\text { Shade Structure } \\
\text { Code (\% shade) }\end{array}$} & \multicolumn{3}{|c|}{ Sprouting percentage } & \multicolumn{3}{c|}{ Success Percentage } \\
\cline { 2 - 7 } & Bapatla method & Puttur method & Mean & Bapatla method & Puttur Method & Mean \\
\hline SS1 (25\%) & 68.76 & 58.93 & 67.79 & 45.90 & 44.38 & 45.14 \\
\hline SS2 (50\%) & 72.38 & 52.18 & 62.28 & 50.10 & 57.14 & 53.62 \\
\hline SS3 (75\%) & 72.94 & 47.81 & 60.38 & 54.48 & 51.23 & 52.86 \\
\hline SS4 (100\%) & 32.19 & 56.41 & 44.30 & 29.71 & 33.91 & 31.81 \\
\hline SS5 (12.5-20\%) & 67.21 & 66.72 & 66.97 & 59.81 & 43.24 & 51.53 \\
\hline SS6 (10-15\%) & 79.23 & 61.04 & 70.16 & 50.48 & 37.82 & 44.15 \\
\hline *SS7 (100\%) & 66.32 & 46.85 & 56.59 & 44.76 & 51.95 & 48.36 \\
\hline SS8 (0\%) & - & - & - & - & - & - \\
\hline Mean & 65.58 & 55.71 & 60.65 & 47.89 & 45.67 & 46.78 \\
\hline CD (p=0.05) & 00.08 & 00.09 & - & 00.08 & 00.11 & - \\
\hline CV \% & 16.62 & 23.70 & - & 17.87 & 24.16 & - \\
\hline
\end{tabular}

Note: The description of structures in first column: SS1, SS2 and SS3 were High density black polythene sheet (HDPS) shade nets; SS4 was a dark room inside the graft shed at cashew research station of Bapatla; SS5 is a trench providing partial shade of 12.5 -20 percent; SS6 is a structure providing partial shade with coconut fronds; *SS7- low cost humid chamber providing only diffused light and with 100 percent shade; while SS8-was without any shade providing complete light of 100 per cent from direct sun in open air.

Table 4: Comparison of successful sprouting of scion under different shade structures during a period of 45 days using two methods of Bapatla and Puttur.

\begin{tabular}{|l|c|c|c|c|c|c|}
\hline \multirow{2}{*}{$\begin{array}{c}\text { Shade Structure Code } \\
\text { (\% shade) }\end{array}$} & \multicolumn{2}{|c|}{$\begin{array}{c}\text { Sprouting percentage in Bapatla method on } \\
\text { the following days after grafting }\end{array}$} & \multicolumn{2}{c|}{$\begin{array}{c}\text { Sprouting percentage in Puttur method on } \\
\text { the following days after grafting }\end{array}$} \\
\cline { 2 - 6 } & $\mathbf{1 5}$ & $\mathbf{3 0}$ & $\mathbf{4 5}$ & $\mathbf{1 5}$ & $\mathbf{3 0}$ & $\mathbf{4 5}$ \\
\hline SS1 (25\%) & 12.00 & 51.81 & 04.95 & 18.68 & 37.42 & 02.86 \\
\hline SS2 (50\%) & 17.52 & 47.05 & 07.81 & 14.65 & 10.47 & 06.86 \\
\hline SS3(75\%) & 10.85 & 58.86 & 03.23 & 09.33 & 12.00 & 06.48 \\
\hline SS4 (100\%) & 08.00 & 23.62 & 00.57 & 26.29 & 27.18 & 02.94 \\
\hline SS5 (12.5-20\%) & 09.90 & 56.38 & 00.95 & 20.24 & 46.47 & 00.00 \\
\hline SS6 (10-15\%) & 10.09 & 68.57 & 00.57 & 29.33 & 30.57 & 01.14 \\
\hline *SS7(100\%) & 08.95 & 46.29 & 11.08 & 06.28 & 40.00 & 00.57 \\
\hline SS8 (0\%) & - & - & - & - & - & - \\
\hline Mean & 11.04 & 50.37 & 04.17 & 17.86 & 34.87 & 02.98 \\
\hline CD (p=0.05) & 00.05 & 00.08 & 00.03 & 00.07 & 00.09 & 00.05 \\
\hline CV (\%) & 28.18 & 16.62 & 29.41 & 30.65 & 23.70 & 48.25 \\
\hline
\end{tabular}

Note: The description of structures in first column: SS1, SS2 and SS3 were High density black polythene sheet (HDPS) shade nets; SS4 was a dark room inside the graft shed at cashew research station of Bapatla; SS5 is a trench providing partial shade of 12.5 -20 percent; SS6 is a structure providing partial shade with coconut fronds; *SS7- low cost humid chamber providing only diffused light and with 100 percent shade; while SS8-was without any shade providing complete light of 100 per cent from direct sun in open air. 
at 5 percent level. Among seven shade structures, the maximum sprouting percentage was recorded by SS2 (17.52) within 15DAG, by SS6 (68.57) within 30DAG and SS7 (11.08) even at 45DAG. Here in SS7, the scion sprouting was continued even at 45 DAG to a greater percentage which is unexpected and a deviation from regular observation at Bapatla. In Puttur technique, SS6 (29.33\%) was the lead structure for shade followed by SS4 (26.29\%) within 15DAG while SS5 was the best within 30DAG followed by SS7. The reason for success might be due to differentially expressed genes responsible for activation of stem growth and cell wall synthesis from 3 to 28th day after grafting by upregulation of genes associated with cell wall synthesis, xylem development [11].Though sprouting was limited after 30DAG, we observed few more scion sprouts in SS2 and SS3 structures that was attributed to the great potential of BPP-6 scion towards delayed cell division for healing and in utilization of available metabolites in warm and entrapped humid conditions under these shade nets [37]. Major success in sprouting within 30 days was supported by previous reports $[12,13]$.

Considering the total number of scion sticks sprouted during 45 DAG, the maximum number was recorded by SS6 (79.23\%) and minimum was recorded by SS4 (32.19\%). It is also clear from the table 4 , that the percentage of sprouting is maximum during 30 DAG in the structures and reduced gradually after 30 DAG indicating precured scion sticks generally takes 15 to 30 days to complete sprouting after grafting by which time the metabolites present in the scion sticks will be utilized by the sprouting buds [14,38] Over all an observed percentage of sprouting in Bapatla method by 45 DAG was 10 to 20 times more than Puttur method and Bapatla method proven successful with 10 to 15 percent increase in success rate when compared to Puttur method under all shade treatments (Table 3).

Interaction effects of month and shade structures (Table 5) revealed maximum sprouting in M3(November) under SS3 (90.68\%), M4 (December) under SS5 (94.68\%), M5 (January) under SS7 (93.36\%). The structure SS4 was observed with very low sprouting except during M1(September) with 57.32 percent. Almost all structures gave more than 50 percent sprouting during seven months of study except SS4 where 100 percent shade was imposed inside a graft-shed. The percentage was observed very low in March (M7) due to high temperatures and relative humidity in March and subsequent months. These temperatures might have increased temperatures under HDPS nets as well. The complete shade (SS4) during some months (M1 and M3) were observed with more than 50 percent sprouting (54-57\%). The success here is purely attributed to diffused light from glass windows of the graftshed during these months. Because graft-shed has no provision for synthesis of assimilates. The partial shade under coconut fronds (SS6) was also a success with more-than 60 percent sprouting during entire experimental period of seven months. This proved that the genotype has definitely a greater influence on the successful graft union leading to eventual success in scion sprouting. All these results were in line with the previous findings in mango and pepper $[39,40]$.

The treatment of complete light conditions (SS8) is a failure as no sprout was observed under Bapatla agro-climatic conditions in both techniques if prepared grafts were left in open sun light during initial 20 days period. The reason for failure under open conditions without shade might be detrimental to newly grafted plants due to high day temperatures which might have caused death of the scion buds and the exhaustion of the moisture in the grafted-region that lead to separation of scion and rootstock without cambial reunion. we observed lot of sprouting on the rootstock below the graft-joint.

Thus, taking this success into consideration, locally available cost-effective shade structures are potential competitors in providing shade during initial 20 days period in place of costly high-density polyethylene shade (HDPS) nets and in achieving equal amount of scion sprouting and success. The shade structures of HDPS providing shade levels in percentages of 25 (SS1), 50 (SS2) and 75 (SS3) were providing light with photosynthetically active radiation (PAR) at 75, 50 and 25 percentage respectively. The trench (SS5) and low-cost humid chamber (SS7) were providing the same amount of humidity and light conditions that were received by the SWGs under HDPS nets as revealed from the observed sprouting data under these shade structures. Thus, the prepared SWGs needed a range of 25 to 80 percent light (with PAR) penetration and high humidity for sprouting and healing of graft union.

Influence of shade on the vegetative growth of soft-wood grafts

The necessary measures of growth as indicated by plant height, leaf number and leaf area were scored to compare the efficiency of shade structures in providing required amount of light, temperature and humidity. The graft growth was observed with significant differences among and within treatments of shade and their interactions with prevailing climate ( $\mathrm{p}=0.05$, Tables 6 to 9$)$.

From table 6, although non-significant differences observed in average graft height, we observed significant differences among the sample mean under different shade structures during different months (Table 9). The grafts prepared and kept in trenches (SS\%, $23.18 \mathrm{~cm}$ ) with partial shade recorded maximum graft height and was supported by previous research reports of CRS, Bapatla [41]. There were significant differences in the number of leaves per graft and leaf area due to different shade treatments. The structures which provide partial shade SS6, (11.66) followed by SS7 (19.81) are found to be useful in the production of leaves with larger leaf area $202.48 \mathrm{~cm}^{2}$ and $200.12 \mathrm{~cm}^{2}$ respectively compared to the structures providing complete shade (SS4,144.91 $\left.\mathrm{cm}^{2}\right)$.The complete shade affected the leaf size by partially preventing the radiation to the growing grafted plants resulting in the reduction of photosynthetic efficiency of the graft. This might have affected leaf area and was supported by previous research findings [42,43]. 
Table 5: Total percent of sprouting in soft-wood grafts by 45 DAG from two methods during the experimental period (M1 to M7) under various shade structures (SS1 to SS8).

\begin{tabular}{|c|c|c|c|c|c|c|c|c|}
\hline \multirow{2}{*}{ Shade Structure Code (\% Shade) } & \multicolumn{8}{|c|}{ Month of Grafting } \\
\hline & M1 & M2 & M3 & M4 & M5 & M6 & M7 & Mean \\
\hline SS1(25\%) & $\begin{array}{c}84.00 \\
(73.32)\end{array}$ & $\begin{array}{c}77.32 \\
(70.64)\end{array}$ & $\begin{array}{c}90.68 \\
(76.00)\end{array}$ & $\begin{array}{c}88.00 \\
(89.48)\end{array}$ & $\begin{array}{c}88.00 \\
(67.32)\end{array}$ & $\begin{array}{c}40.00 \\
(18.68)\end{array}$ & $\begin{array}{c}13.32 \\
(17.32)\end{array}$ & $\begin{array}{c}67.79 \\
(58.93)\end{array}$ \\
\hline SS2(50\%) & $\begin{array}{c}65.32 \\
(80.00)\end{array}$ & $\begin{array}{c}68.00 \\
(54.68)\end{array}$ & $\begin{array}{c}62.64 \\
(58.68)\end{array}$ & $\begin{array}{c}94.68 \\
(46.68)\end{array}$ & $\begin{array}{c}65.36 \\
(20.00)\end{array}$ & $\begin{array}{c}70.64 \\
(46.68)\end{array}$ & $\begin{array}{c}80.00 \\
(58.64)\end{array}$ & $\begin{array}{c}72.38 \\
(52.18)\end{array}$ \\
\hline SS3(75\%) & $\begin{array}{c}97.32 \\
(60.00)\end{array}$ & $\begin{array}{c}17.32 \\
(32.00)\end{array}$ & $\begin{array}{c}84.00 \\
(53.32)\end{array}$ & $\begin{array}{c}80.00 \\
(86.68)\end{array}$ & $\begin{array}{c}90.64 \\
(24.00)\end{array}$ & $\begin{array}{c}82.64 \\
(54.68)\end{array}$ & $\begin{array}{c}58.68 \\
(24.00)\end{array}$ & $\begin{array}{c}72.94 \\
(47.81)\end{array}$ \\
\hline SS4(100\%) & $\begin{array}{c}57.32 \\
(38.64)\end{array}$ & $\begin{array}{c}28.00 \\
(69.32)\end{array}$ & $\begin{array}{c}54.68 \\
(63.32)\end{array}$ & $\begin{array}{c}33.32 \\
(45.32)\end{array}$ & $\begin{array}{c}32.00 \\
(56.00)\end{array}$ & $\begin{array}{c}18.68 \\
(56.00)\end{array}$ & $\begin{array}{c}01.32 \\
(66.40)\end{array}$ & $\begin{array}{c}32.19 \\
(56.41)\end{array}$ \\
\hline SS5(12.5-20\%) & $\begin{array}{c}85.32 \\
(97.82)\end{array}$ & $\begin{array}{c}60.00 \\
(81.32)\end{array}$ & $\begin{array}{c}98.68 \\
(76.00)\end{array}$ & $\begin{array}{c}84.00 \\
(74.68)\end{array}$ & $\begin{array}{c}73.32 \\
(43.08)\end{array}$ & $\begin{array}{c}48.00 \\
(56.00)\end{array}$ & $\begin{array}{c}29.32 \\
(38.64)\end{array}$ & $\begin{array}{c}67.21 \\
(66.72)\end{array}$ \\
\hline SS6 (10-15\%) & $\begin{array}{c}81.32 \\
(64.68)\end{array}$ & $\begin{array}{c}77.32 \\
(69.36)\end{array}$ & $\begin{array}{c}81.36 \\
(72.00)\end{array}$ & $\begin{array}{c}82.68 \\
(96.00)\end{array}$ & $\begin{array}{c}82.64 \\
(52.00)\end{array}$ & $\begin{array}{c}81.32 \\
(60.00)\end{array}$ & $\begin{array}{c}68.00 \\
(13.36)\end{array}$ & $\begin{array}{c}79.23 \\
(61.04)\end{array}$ \\
\hline *SS7 (100\%) & $\begin{array}{c}64.00 \\
(54.68)\end{array}$ & $\begin{array}{c}68.00 \\
(44.00)\end{array}$ & $\begin{array}{c}65.32 \\
(54.68)\end{array}$ & $\begin{array}{c}93.36 \\
(68.00)\end{array}$ & $\begin{array}{c}81.32 \\
(50.68)\end{array}$ & $\begin{array}{c}41.32 \\
(19.96)\end{array}$ & $\begin{array}{c}16.00 \\
(36.00)\end{array}$ & $\begin{array}{c}66.32 \\
(46.85)\end{array}$ \\
\hline SS8 (0) & - & - & - & - & - & - & - & - \\
\hline Mean & $\begin{array}{c}76.58 \\
(66.94) \\
\end{array}$ & $\begin{array}{c}56.57 \\
(60.18)\end{array}$ & $\begin{array}{c}68.66 \\
(64.84)\end{array}$ & $\begin{array}{c}82.49 \\
(72.39) \\
\end{array}$ & $\begin{array}{c}73.32 \\
(44.77)\end{array}$ & $\begin{array}{c}54.66 \\
(44.56)\end{array}$ & $\begin{array}{c}38.09 \\
(36.33)\end{array}$ & \\
\hline $\begin{array}{l}\text { SEM } \\
M / S S \\
M \times S S\end{array}$ & \multicolumn{8}{|c|}{$\begin{array}{l}01(0.02) \\
03(0.05)\end{array}$} \\
\hline $\begin{array}{l}\text { CD (p=0.05) } \\
M / S S \\
\text { Mx SS }\end{array}$ & \multicolumn{7}{|c|}{$0.03(0.05)$} & \\
\hline $\mathrm{CV}(\%)$ & \multicolumn{8}{|c|}{$29.41(48.25)$} \\
\hline
\end{tabular}

Note: The description of structures in first column: SS1, SS2 and SS3 were High density black polythene sheet (HDPS) shade nets; SS4 was a dark room inside the graft shed at cashew research station of Bapatla; SS5 is a trench providing partial shade of 12.5-20 percent; SS6 is a structure providing partial shade with coconut fronds; *SS7- low cost humid chamber providing only diffused light and with 100 percent shade; while SS8-was without any shade providing complete light of 100 per cent from direct sun in open air. The columns from 2 to 8 include data on the total percent of scion sprouts observed from September (M1) to March(M7) for Bapatla method. The column data in the parenthesis below Bapatla data were the scion sprout data observed in Puttur method.

Table 6: Mean growth observed in soft-wood grafts raised under different shade structures at 90 days after grafting (DAG).

\begin{tabular}{|l|c|c|c|}
\hline \multirow{2}{*}{$\begin{array}{c}\text { Shade Structure Code } \\
\text { (\% Shade) }\end{array}$} & \multicolumn{3}{|c|}{ Graft growth at 90 days after grafting } \\
\cline { 2 - 4 } & Plant Height (cm) & Number of leaves & Total Leaf Area (cm $\mathbf{~}$ \\
\hline SS1(25\%) & 22.02 & 09.76 & 194.05 \\
& $(25.2)$ & $(10.1)$ & $(168.6)$ \\
\hline SS2(50\%) & 21.57 & 10.40 & 188.52 \\
& $(28.23)$ & $(9.7)$ & $(172.6)$ \\
\hline SS3(75\%) & 21.25 & 10.09 & 174.94 \\
& $(25.9)$ & $(9.9)$ & $(145.6)$ \\
\hline SS4(100\%) & 21.78 & 08.77 & 144.94 \\
& $(25.9)$ & $(8.2)$ & $(125.8)$ \\
\hline SS5(12.5-20\%) & 23.18 & 19.81 & 200.12 \\
& $(25.8)$ & $(12.0)$ & $(191.6)$ \\
\hline SS6 (10-15\%) & 22.24 & 11.66 & 202.48 \\
& $(25.2)$ & $(10.0)$ & $153.8)$ \\
\hline *SS7(100\%) & 22.30 & 09.24 & 170.97 \\
& $(27.1)$ & $(9.7)$ & - \\
\hline SS8(0) & - & - & 182.28 \\
\hline Mean & 22.05 & 11.39 & $(162.8)$ \\
\hline CD (p=0.05) & $(26.19)$ & $(9.94)$ & 22.50 \\
& 01.13 & 01.36 & $(25.3)$ \\
\hline CV (\%) & $(1.34)$ & $(1.35)$ & 19.84 \\
& 08.47 & 22.22 & $(25.39)$ \\
\hline
\end{tabular}

Note: The description of structures in first column: SS1, SS2 and SS3 were High density black polythene sheet (HDPS) shade nets; SS4 was a dark room inside the graft shed at cashew research station of Bapatla; SS5 is a trench providing partial shade of 12.5-20 percent; SS6 is a structure providing partial shade with coconut fronds; *SS7- low cost humid chamber providing only diffused light and with 100 percent shade; while SS8-was without any shade providing complete light of 100 per cent from direct sun in open air. The column data from 2 to 4 columns is the average data obtained from Bapatla method and the data in parenthesis is obtained from Puttur method from two factors of shade. 
Table 7: Total leaf area $\left(\mathrm{cm}^{2}\right)$ of soft-wood grafts at 90 days after grafting (DAG) during the experimental period (M1 to M7) under various shade structures (SS1 to SS8).

\begin{tabular}{|c|c|c|c|c|c|c|c|c|}
\hline \multirow{2}{*}{ Shade Structure Code (\% Shade) } & \multicolumn{8}{|c|}{ Month of Grafting } \\
\hline & M1 & M2 & M3 & M4 & M5 & M6 & M7 & Mean \\
\hline \multirow[t]{2}{*}{ SS1(25\%) } & 296.9 & 166.9 & 158.3 & 213.8 & 192.6139 .3 & 183.6 & 146.3 & 194.1 \\
\hline & 189.4 & 200.1 & 192.2 & 196.9 & & 174.6 & 087.8 & 168.6 \\
\hline \multirow[t]{2}{*}{ SS2(50\%) } & 271.6 & 190.8 & 126.7 & 169.2 & 204.8146 .3 & 195.7 & 160.9 & 188.5 \\
\hline & 196.3 & 167.0 & 115.7 & 235.9 & & 185.3 & 161.4 & 172.6 \\
\hline \multirow[t]{2}{*}{ SS3(75\%) } & 169.5 & 158.0 & 116.0 & 201.9 & 161.7163 .5 & 160.5 & 257.0 & 174.9 \\
\hline & 111.4 & 100.4 & 77.7 & 261.4 & & 163.0 & 141.9 & 145.6 \\
\hline \multirow[t]{2}{*}{ SS4(100\%) } & 223.6 & 118.6 & 065.4 & 126.8 & 179.9097.4 & 151.9 & 148.2 & 144.9 \\
\hline & 199.7 & 120.4 & 70.4 & 135.6 & & 097.9 & 160.0 & 125.8 \\
\hline \multirow[t]{2}{*}{ SS5(12.5-20\%) } & 390.5 & 108.1 & 109.8 & 211.9 & 181.5268 .3 & 248.9 & 150.2 & 200.1 \\
\hline & 317.1 & 116.7 & 127.9 & 147.3 & & 153.9 & 210.1 & 191.6 \\
\hline \multirow[t]{2}{*}{ SS6 (10-15\%) } & 305.1 & 233.9 & 116.5 & 193.7 & 197.9093.2 & 141.8 & 228.5 & 202.5 \\
\hline & 334.3 & 119.9 & 131.5 & 181.6 & & 096.2 & 120.1 & 153.8 \\
\hline \multirow[t]{2}{*}{ *SS7(100\%) } & 288.0 & 195.7 & 059.5 & 260.4 & 146.6150 .3 & 120.5 & 126.1 & 171.0 \\
\hline & 288.0 & 285.4 & 89.4 & 205.5 & & 136.5 & 112.4 & 181.6 \\
\hline SS8(0) & - & - & - & - & - & - & - & - \\
\hline \multirow{2}{*}{ Mean } & 277.9 & 167.4 & 107.5 & 196.8 & 180.7151 & 171.8 & 173.9 & \\
\hline & 233.0 & 170.0 & 115.0 & 194.0 & & 143.0 & 142.0 & \\
\hline \multicolumn{9}{|l|}{ SEM } \\
\hline $\mathrm{M} / \mathrm{SS}$ & \multicolumn{8}{|c|}{$\begin{array}{c}8.12(9.12) \\
21.48(24.12)\end{array}$} \\
\hline M x SS & \multirow{2}{*}{\multicolumn{8}{|c|}{$21.48(24.12)$}} \\
\hline $\mathrm{CD}(\mathrm{p}=0.05)$ & & & & & & & & \\
\hline M/SS & \multicolumn{8}{|c|}{$59.50(25.33)$} \\
\hline M x SS & \multicolumn{8}{|c|}{$22.50(66.9)$} \\
\hline CV (\%) & \multicolumn{8}{|c|}{$19.84(25.39)$} \\
\hline
\end{tabular}

Note: The description of structures in first column: SS1, SS2 and SS3 were High density black polythene sheet (HDPS) shade nets; SS4 was a dark room inside the graft shed at cashew research station of Bapatla; SS5 is a trench providing partial shade of 12.5-20 percent; SS6 is a structure providing partial shade with coconut fronds; *SS7- low cost humid chamber providing only diffused light and with 100 percent shade; while SS8-was without any shade providing complete light of 100 per cent from direct sun in open air. The column data from M1 to M7 and mean were total leaf area observed from September (M1) to March (M7) at 90 DAG in each treatment of shade under Bapatla method while the data highlighted in bold font immediately below these Bapatla values or in parenthesis pertains to Puttur method.

Table 8: Total number of leaves produced by soft-wood grafts under various shade structures (SS1 to SS8) during the experimental period (M1 to M7).

\begin{tabular}{|c|c|c|c|c|c|c|c|c|}
\hline \multirow{2}{*}{ Shade Structure Code (\% Shade) } & \multicolumn{8}{|c|}{ Month of Grafting } \\
\hline & M1 & M2 & M3 & M4 & M5 & M6 & M7 & Mean \\
\hline \multirow[t]{2}{*}{ SS1(25\%) } & 11.1 & 11.1 & 09.3 & 08.2 & 10.9 & 10.4 & 07.3 & 09.76 \\
\hline & $(8.3)$ & $(8.3)$ & $(12)$ & $(9.4)$ & $(10.4)$ & (11.1) & $(11.1)$ & $(10.1)$ \\
\hline SS2(50\%) & $\begin{array}{c}08.8 \\
(8.0)\end{array}$ & $\begin{array}{l}10.5 \\
(11)\end{array}$ & $\begin{array}{c}07.0 \\
(7.3)\end{array}$ & $\begin{array}{c}09.7 \\
(13.3)\end{array}$ & $\begin{array}{c}16.5 \\
(10.6)\end{array}$ & $\begin{array}{c}10.3 \\
(11.0)\end{array}$ & $\begin{array}{l}10.0 \\
(6.6)\end{array}$ & $\begin{array}{c}10.40 \\
(9.7)\end{array}$ \\
\hline SS3(75\%) & $\begin{array}{l}10.5 \\
(4.9)\end{array}$ & $\begin{array}{l}05.7 \\
(12)\end{array}$ & $\begin{array}{c}09.3 \\
(6.7)\end{array}$ & $\begin{array}{c}12.3 \\
(13.3)\end{array}$ & $\begin{array}{c}13.7 \\
(12.1)\end{array}$ & $\begin{array}{c}10.2 \\
(10.3)\end{array}$ & $\begin{array}{c}08.9 \\
(10.3)\end{array}$ & $\begin{array}{l}10.10 \\
(9.9)\end{array}$ \\
\hline SS4(100\%) & $\begin{array}{l}09.3 \\
(7.2)\end{array}$ & $\begin{array}{l}05.9 \\
(8.1)\end{array}$ & $\begin{array}{c}08.0 \\
(6.9)\end{array}$ & $\begin{array}{c}08.7 \\
(13.5)\end{array}$ & $\begin{array}{c}14.7 \\
(10.3)\end{array}$ & $\begin{array}{l}08.9 \\
(6.3)\end{array}$ & $\begin{array}{l}05.9 \\
(5.3)\end{array}$ & $\begin{array}{c}08.80 \\
(9.9)\end{array}$ \\
\hline SS5(12.5-20\%) & $\begin{array}{l}10.2 \\
(9.3)\end{array}$ & $\begin{array}{c}08.0 \\
(11.6)\end{array}$ & $\begin{array}{l}07.7 \\
(12)\end{array}$ & $\begin{array}{c}10.7 \\
(14.7)\end{array}$ & $\begin{array}{c}11.8 \\
(11.5)\end{array}$ & $\begin{array}{c}11.3 \\
(12.6)\end{array}$ & $\begin{array}{c}09.0 \\
(8)\end{array}$ & $\begin{array}{c}09.80 \\
(8.2)\end{array}$ \\
\hline SS6 (10-15\%) & $\begin{array}{c}12.1 \\
(10.4)\end{array}$ & $\begin{array}{c}11.9 \\
(10.4)\end{array}$ & $\begin{array}{c}17.0 \\
(8)\end{array}$ & $\begin{array}{c}17.0 \\
(12.7)\end{array}$ & $\begin{array}{l}13.4 \\
(7.7)\end{array}$ & $\begin{array}{c}09.4 \\
(10.4)\end{array}$ & $\begin{array}{c}09.1 \\
(10.7)\end{array}$ & $\begin{array}{l}11.7 \\
(12)\end{array}$ \\
\hline *SS7(100\%) & $\begin{array}{c}12.0 \\
(12.0)\end{array}$ & $\begin{array}{c}06.6 \\
(8.0)\end{array}$ & $\begin{array}{c}09.0 \\
(9)\end{array}$ & $\begin{array}{c}09.0 \\
(13.0)\end{array}$ & $\begin{array}{l}16.3 \\
(8.2)\end{array}$ & $\begin{array}{c}06.2 \\
(8.7)\end{array}$ & $\begin{array}{l}07.7 \\
(8.7)\end{array}$ & $\begin{array}{l}09.2 \\
(10)\end{array}$ \\
\hline SS8 (0) & - & - & - & - & - & - & - & - \\
\hline Mean & $\begin{array}{l}10.6 \\
(8.5)\end{array}$ & $\begin{array}{l}08.5 \\
(9.9)\end{array}$ & $\begin{array}{r}08.1 \\
(8.8)\end{array}$ & $\begin{array}{c}10.8 \\
(12.8)\end{array}$ & $\begin{array}{c}13.9 \\
(10.1)\end{array}$ & $\begin{array}{l}09.5 \\
(10)\end{array}$ & $\begin{array}{c}08.2 \\
(8.6)\end{array}$ & \\
\hline $\begin{array}{l}\text { SEM } \\
\text { M/SS } \\
\text { M x SS }\end{array}$ & \multicolumn{8}{|c|}{$0.49(0.49)$} \\
\hline $\mathrm{CD}(\mathrm{p}=0.05)$ & \multicolumn{8}{|c|}{$1.30(1.29)$} \\
\hline $\mathrm{M} / \mathrm{SS}$ & \multicolumn{8}{|c|}{$3.6(1.35)$} \\
\hline M x SS & \multirow{2}{*}{\multicolumn{8}{|c|}{$\frac{1.36(3.56)}{22.22(2263)}$}} \\
\hline CV (\%) & & & & & $22.22(22.63)$ & & & \\
\hline
\end{tabular}

Note: The description of structures in first column: SS1, SS2 and SS3 were High density black polythene sheet (HDPS) shade nets; SS4 was a dark room inside the graft shed at cashew research station of Bapatla; SS5 is a trench providing partial shade of 12.5-20 percent; SS6 is a structure providing partial shade with coconut fronds; *SS7- low cost humid chamber providing only diffused light and with 100 percent shade; while SS8-was without any shade providing complete light of 100 per cent from direct sun in open air. The column data from M1 to M7 and mean were total number of leaves observed from September (M1) to March (M7) at 90 DAG in each treatment of shade under Bapatla method while the data in parenthesis pertains to Puttur method. 
Table 9: Total graft height (cm) observed at 90 days after grafting under various shade structures (SS1 to SS8) during the experimental period (M1 to M7).

\begin{tabular}{|c|c|c|c|c|c|c|c|c|}
\hline \multirow{2}{*}{ Shade Structure Code (\% Shade) } & \multicolumn{8}{|c|}{ Month of Grafting } \\
\hline & M1 & M2 & M3 & M4 & M5 & M6 & M7 & Mean \\
\hline SS1 (25\%) & $\begin{array}{l}22.4 \\
(23) \\
\end{array}$ & $\begin{array}{c}22.0 \\
(23.6) \\
\end{array}$ & $\begin{array}{c}20.8 \\
(28.7) \\
\end{array}$ & $\begin{array}{c}20.9 \\
(27.7) \\
\end{array}$ & $\begin{array}{l}22.3 \\
(27) \\
\end{array}$ & $\begin{array}{c}23.5 \\
(22.9) \\
\end{array}$ & $\begin{array}{c}22.3 \\
(23.2) \\
\end{array}$ & $\begin{array}{c}22.0 \\
(25.2) \\
\end{array}$ \\
\hline SS2 (50\%) & $\begin{array}{c}20.0 \\
(25.2)\end{array}$ & $\begin{array}{c}20.7 \\
(24.8) \\
\end{array}$ & $\begin{array}{c}20.2 \\
(29.2) \\
\end{array}$ & $\begin{array}{c}21.5 \\
(32.4) \\
\end{array}$ & $\begin{array}{l}27.1 \\
(30)\end{array}$ & $\begin{array}{c}21.3 \\
(33.2) \\
\end{array}$ & $\begin{array}{c}20.2 \\
(23.8) \\
\end{array}$ & $\begin{array}{c}21.6 \\
(28.23) \\
\end{array}$ \\
\hline SS3 (75\%) & $\begin{array}{c}21.2 \\
(23.3)\end{array}$ & $\begin{array}{c}20.4 \\
(23.9)\end{array}$ & $\begin{array}{c}20.5 \\
(26.3) \\
\end{array}$ & $\begin{array}{c}22.3 \\
(33.8) \\
\end{array}$ & $\begin{array}{c}23.2 \\
(25.9) \\
\end{array}$ & $\begin{array}{c}19.2 \\
(25.8) \\
\end{array}$ & $\begin{array}{c}22.0 \\
(22.5) \\
\end{array}$ & $\begin{array}{c}21.3 \\
(25.9)\end{array}$ \\
\hline SS4 (100\%) & $\begin{array}{l}20.2 \\
(23) \\
\end{array}$ & $\begin{array}{c}21.6 \\
(24.2) \\
\end{array}$ & $\begin{array}{c}22.5 \\
(28.7) \\
\end{array}$ & $\begin{array}{c}22.0 \\
(29.1)\end{array}$ & $\begin{array}{c}25.1 \\
(28.3) \\
\end{array}$ & $\begin{array}{c}19.8 \\
(24.8) \\
\end{array}$ & $\begin{array}{c}21.3 \\
(23.2) \\
\end{array}$ & $\begin{array}{c}21.8 \\
(25.9) \\
\end{array}$ \\
\hline SS5 (12.5-20\%) & $\begin{array}{c}22.7 \\
(29.1) \\
\end{array}$ & $\begin{array}{c}20.5 \\
(22.5) \\
\end{array}$ & $\begin{array}{c}22.3 \\
(29.7) \\
\end{array}$ & $\begin{array}{c}26.5 \\
(26.7) \\
\end{array}$ & $\begin{array}{l}26.3 \\
(28) \\
\end{array}$ & $\begin{array}{c}23.5 \\
(24.2)\end{array}$ & $\begin{array}{c}20.5 \\
(20.3) \\
\end{array}$ & $\begin{array}{c}23.2 \\
(25.8)\end{array}$ \\
\hline SS6 (10-15\%) & $\begin{array}{c}23.0 \\
(25.5) \\
\end{array}$ & $\begin{array}{c}22.0 \\
(26.7)\end{array}$ & $\begin{array}{c}20.2 \\
(26.8) \\
\end{array}$ & $\begin{array}{c}22.0 \\
(23.6) \\
\end{array}$ & $\begin{array}{c}23.9 \\
(27.8) \\
\end{array}$ & $\begin{array}{c}21.8 \\
(23.3) \\
\end{array}$ & $\begin{array}{c}22.8 \\
(22.7) \\
\end{array}$ & $\begin{array}{c}22.2 \\
(25.2) \\
\end{array}$ \\
\hline *SS7 (100\%) & $\begin{array}{c}23.3 \\
(29.8) \\
\end{array}$ & $\begin{array}{l}23.1 \\
(26) \\
\end{array}$ & $\begin{array}{c}20.7 \\
(29.5) \\
\end{array}$ & $\begin{array}{c}25.8 \\
(27.3) \\
\end{array}$ & $\begin{array}{c}25.6 \\
(31.9) \\
\end{array}$ & $\begin{array}{c}19.0 \\
(24.8) \\
\end{array}$ & $\begin{array}{c}19.6 \\
(20.8) \\
\end{array}$ & $\begin{array}{c}22.3 \\
(27.1) \\
\end{array}$ \\
\hline SS8 (0) & - & - & - & - & - & - & - & - \\
\hline Mean & $\begin{array}{c}21.8 \\
(25.5)\end{array}$ & $\begin{array}{c}21.3 \\
(24.5) \\
\end{array}$ & $\begin{array}{c}21.0 \\
(28.4)\end{array}$ & $\begin{array}{c}23.0 \\
(28.6) \\
\end{array}$ & $\begin{array}{c}24.8 \\
(28.4) \\
\end{array}$ & $\begin{array}{c}21.2 \\
(25.5)\end{array}$ & $\begin{array}{c}21.3 \\
(22.2)\end{array}$ & \\
\hline $\begin{array}{l}\text { SEM } \\
M / S S \\
M \times S S\end{array}$ & \multicolumn{8}{|c|}{$\begin{array}{l}0.41(0.48) \\
1.08(1.28)\end{array}$} \\
\hline $\begin{array}{l}\mathrm{CD}(\mathrm{p}=0.05) \\
\mathrm{M} / \mathrm{SS} \\
\mathrm{M} \times \mathrm{SS}\end{array}$ & & & & \multicolumn{3}{|c|}{$1.13(1.34)$} & & \\
\hline CV (\%) & \multicolumn{8}{|c|}{$8.47(8.46)$} \\
\hline
\end{tabular}

Note: The description of structures in first column: SS1, SS2 and SS3 were High density black polythene sheet (HDPS) shade nets; SS4 was a dark room inside the graft shed at cashew research station of Bapatla; SS5 is a trench providing partial shade of 12.5-20 percent; SS6 is a structure providing partial shade with coconut fronds; *SS7- low cost humid chamber providing only diffused light and with 100 percent shade; while SS8-was without any shade providing complete light of 100 per cent from direct sun in open air. The column data from M1 to M7 and mean were total graft height observed from September (M1) to March (M7) at 90 DAG in each treatment of shade under Bapatla method while the data in parenthesis pertains to Puttur method.

Interactions effects of shade and month on vegetative growth of softwood grafts

The shade structure SS5 and SS6 gave maximum average leaf area per graft (Table 7) during experimental period. September is the best month for all the structures providing shade to produce maximum leaf area. The structures SS1, SS3, SS5 and SS7 recorded maximum in December month while only SS3 and SS6 were observed with maximum leaf area in the month of March. The reason for high success in September might be conducive warm climate with high rainfall and humidity $\left(24-32^{\circ} \mathrm{C}, 80 \% \mathrm{RH}, 37 \mathrm{~mm}\right.$ rainfall). The success achieved due to HDPS nets (SS1, SS2 and SS3) might be because of the heat and humidity entrapped by the plastic nets inside the microclimate of growing SWGs that have caused the increased total leaf area as similar to the structure SS7 in supplying photosynthates and providing maximum PAR. Though the leaf area is not more than $200 \mathrm{~cm}^{2}$ in the rest of the treatments, combinations or their interactions, but it is not less than $115 \mathrm{~cm}^{2}$ except in treatment interactions of M3 with SS4 and M3 with SS7 indicating all treatments of shade were very good in providing good graft growth. As explained earlier for SS4 which was observed with least amount of leaf area due to non-provision of light conditions except during September when grafts received some amount of diffused light through windows. Over all, leaf area is completely dependent on the genotype of the cultivar and light perception to provide photosynthetically active radiation to the growing grafts at CRS in Bapatla. These results are in line with previous findings [42,43].

Number of leaves per graft (Table 8) were more (9.76 to 11.7) in SS1 to SS3 as well as SS6 and in September, December to February months. In all the shade treatments, and their interactions with month of grafting, the SWGs produced a minimum of six leaves on an average and a maximum of 17 leaves per graft. The potential shade structure SS6 was producing a range of 8.7 to 17 leaves during the experimental period. This provided solid proof in sustainable use of dried coconut fronds as a shade for SWGs to improve their growth. The increased number of leaves also contributed increased total leaf area in some treatments and success in both traits could be attributed to the early sprouting of scion under these structures and efficient utilization of available photosynthates (Table 4). The results were supported by previous findings [44]

Graft height (Table 9) was equal to $20 \mathrm{~cm}$ in all the shade treatments and in their interactions with month of grafting. Although, 
we observed an exceptional performance of 23 to $27 \mathrm{~cm}$ in September (M1) under structures SS6 and SS7, in October (M2) under SS5, in December (M4) under SS7 while under SS2 to SS7 in January and SS1 in February months. The results are supported (Patil, 1983, Anonymous 1994). Over all the maximum graft height was realized due to the active transport of growth promoting hormones like GA synthesized from the source (rootstock) to sink (scion), production of a greater number of leaves and larger size leaves under different shade treatments and favorable climate conditions for biosynthesis of growth hormones. From this data it is concluded that the structure SS5 is potential shade structure producing 22-23 cm height on an average followed by SS7 and SS6. These structures were equally competing with HDPS nets producing graft heights of 20 to $27 \mathrm{~cm}$. Another reason for increase in graft height might be due to phototropism effect of plants in search of light for photosynthesis under these structures that enhanced stress induced synthesis of growth promoting hormones like Gibberellins. At farmers or business level, cost-benefit ratio is important factor besides climate sustainability. Therefore, provision of shade from locally available plant materials like coconut fronds is a viable option economically as it was observed with more than 20 cm graft height in all the months and equally potential to trench with partial shade (SS5). The reason for this could be attributed to availability of uninterrupted light with PAR, humidity, rainfall to the growing grafts $[26,28,29]$.

\section{Success and mortality of softwood grafts}

The success of the grafts was scored by measuring survival and mortality of grafts at 30, 60 and 90DAG (Tables 2, 3, 10, 11 and 12) for both techniques and were observed with significant differences under various shade structures. High humidity is the key feature of the tropical and coastal regions. But in Bapatla, during summer, day temperatures were at its maximum which were elevated even higher due to the reflected radiation from sandy soils. This caused reduced success rate in open conditions providing 100 percent light and during summer months of the experiment.

Table 10: Total percent of successful soft-wood grafts produced by 90 days under various shade structures (SS1 to SS8) during the experimental period (M1 to M7).

\begin{tabular}{|c|c|c|c|c|c|c|c|c|}
\hline \multirow{2}{*}{ Shade Structure Code (\% Shade) } & \multicolumn{8}{|c|}{ Month of Grafting } \\
\hline & M1 & M2 & M3 & M4 & M5 & M6 & M7 & Mean \\
\hline SS1(25\%) & 60.0 & 41.3 & 58.7 & 61.3 & 45.3 & 46.7 & 08.0 & 45.9 \\
\hline SS2(50\%) & 42.7 & 50.7 & 44.0 & 82.7 & 48.0 & 69.3 & 13.3 & 50.1 \\
\hline SS3(75\%) & 42.7 & 57.3 & 70.7 & 46.7 & 64.0 & 65.3 & 34.7 & 54.5 \\
\hline SS4(100\%) & 34.7 & 25.3 & 24.7 & 10.7 & 38.0 & 41.3 & 33.3 & 29.7 \\
\hline SS5(12.5-20\%) & 81.3 & 61.3 & 70.7 & 70.7 & 70.7 & 53.3 & 10.7 & 59.8 \\
\hline SS6 (10-15\%) & 65.3 & 32.0 & 38.7 & 64.0 & 65.3 & 68.0 & 20.0 & 50.5 \\
\hline *SS7 $(100 \%)$ & 42.7 & 38.7 & 49.3 & 78.7 & 61.3 & 21.3 & 21.3 & 44.8 \\
\hline SS8(0) & - & - & - & - & - & - & - & - \\
\hline Mean & 52.7 & 43.8 & 50.9 & 59.2 & 56.1 & 52.2 & 20.2 & \\
\hline $\begin{array}{l}\text { SEM } \\
M / S S \\
M \times S S\end{array}$ & \multicolumn{8}{|c|}{$\begin{array}{l}0.03 \\
0.08\end{array}$} \\
\hline $\begin{array}{l}\mathrm{CD}(\mathrm{p}=0.05) \\
\mathrm{M} / \mathrm{SS} \\
\mathrm{M} \times \mathrm{SS}\end{array}$ & \multicolumn{8}{|c|}{$\begin{array}{l}0.08 \\
0.22 \\
\end{array}$} \\
\hline $\mathrm{CV}(\%)$ & \multicolumn{8}{|c|}{17.87} \\
\hline
\end{tabular}

Note: The description of structures in first column: SS1, SS2 and SS3 were High density black polythene sheet (HDPS) shade nets; SS4 was a dark room inside the graft shed at cashew research station of Bapatla; SS5 is a trench providing partial shade of 12.5 -20 percent; SS6 is a structure providing partial shade with coconut fronds; *SS7- low cost humid chamber providing only diffused light and with 100 percent shade; while SS8-was without any shade providing complete light of 100 per cent from direct sun in open air. The column data from M1 to M7 and mean were total percent of successful graft observed from September (M1) to March (M7) at 90 DAG in each treatment of shade under Bapatla method.

The percentage of successful grafts (Tables 3 and 10) significantly influenced by shade structures among which, trench provided with partial shade (SS5) recorded maximum success (59.81\%) followed by SS3 and SS6. The trenches were made to a depth of 3 feet in a way to maintain constant temperatures and high relative humidity as achieved by ventilating twice, for irrigation and to provide condensed water left on the covering blue sheet to the growing grafts. The prevailing optimum favorable temperatures in the trenches were conducive for quick healing of the cambial region in the grafted joint. The lowest success was recorded by the grafts under 100 percent shade where there is no provision for synthesis of assimilates by the sprouted scion bud sticks. Similar results were observed by previous researchers in mango [45] and Cashew [40]. Therefore, SWG require structures like SS2, SS3, SS5 and SS6 that provide partial shade of at least 50 percent under Bapatla conditions. 
Table 11: Mortality (\%) of soft-wood grafts observed from 30 to 90 days after grafting (DAG) under various shade structures (SS1 to SS8) using Bapatla and Puttur Techniques.

\begin{tabular}{|l|c|c|c|c|c|c|}
\hline \multirow{2}{*}{$\begin{array}{c}\text { Shade Structure Code } \\
\text { (\% shade) }\end{array}$} & \multicolumn{4}{c|}{$\begin{array}{c}\text { Mortality (\%) in Bapatla method on the } \\
\text { following days after grafting }\end{array}$} & \multicolumn{2}{c|}{$\begin{array}{c}\text { Mortality (\%) in Puttur method on the } \\
\text { following days after grafting }\end{array}$} \\
\cline { 2 - 7 } & $\mathbf{3 0}$ & $\mathbf{6 0}$ & $\mathbf{9 0}$ & $\mathbf{3 0}$ & $\mathbf{6 0}$ & $\mathbf{9 0}$ \\
\hline SS1 (25\%) & 41.91 & 08.62 & 02.81 & 43.62 & 11.81 & 00.57 \\
\hline SS2 (50\%) & 38.00 & 10.43 & 00.90 & 32.38 & 08.38 & 00.00 \\
\hline SS3(75\%) & 34.29 & 07.05 & 00.00 & 33.91 & 10.67 & 00.00 \\
\hline SS4 (100\%) & 54.29 & 12.19 & 04.14 & 55.24 & 10.28 & 00.57 \\
\hline SS5 (12.5-20\%) & 31.43 & 02.14 & 00.85 & 48.00 & 08.76 & 00.00 \\
\hline SS6 (10-15\%) & 38.29 & 07.81 & 02.29 & 49.14 & 06.29 & 00.00 \\
\hline *SS7 (100\%) & 40.38 & 14.86 & 01.90 & 38.46 & 09.33 & 08.76 \\
\hline SS8 (0\%) & - & - & - & - & - & - \\
\hline Mean & 39.80 & 09.01 & 1.84 & 42.96 & 9.36 & 1.41 \\
\hline SEM & 0.03 & 0.02 & 0.02 & 0.03 & 0.03 & 0.01 \\
\hline CD (p=0.05) & 0.08 & 0.05 & 0.05 & 0.09 & 0.07 & 0.01 \\
\hline CV (\%) & 19.07 & 28.96 & 51.63 & 20.06 & 41.76 & 28.33 \\
\hline
\end{tabular}

Note: The description of structures in first column: SS1, SS2 and SS3 were High density black polythene sheet (HDPS) shade nets; SS4 was a dark room inside the graft shed at cashew research station of Bapatla; SS5 is a trench providing partial shade of 12.5-20 percent; SS6 is a structure providing partial shade with coconut fronds; *SS7- low cost humid chamber providing only diffused light and with 100 percent shade; while SS8-was without any shade providing complete light of 100 per cent from direct sun in open air.

Table 12: Success (\%) of soft-wood grafts observed from 30 to 90 days after grafting (DAG) under various shade structures (SS1 to SS8) using Bapatla and Puttur Techniques.

\begin{tabular}{|l|c|c|c|c|c|c|}
\hline \multirow{2}{*}{$\begin{array}{c}\text { Shade Structure Code } \\
\text { (\% shade) }\end{array}$} & \multicolumn{2}{c|}{$\begin{array}{c}\text { Success (\%) in Bapatla method on the } \\
\text { following days after grafting }\end{array}$} & \multicolumn{2}{c|}{$\begin{array}{c}\text { Success (\%) in Puttur method on the } \\
\text { following days after grafting }\end{array}$} \\
\cline { 2 - 7 } & $\mathbf{3 0}$ & $\mathbf{6 0}$ & $\mathbf{9 0}$ & $\mathbf{3 0}$ & $\mathbf{6 0}$ & $\mathbf{9 0}$ \\
\hline SS1 (25\%) & 58.67 & 48.95 & 45.90 & 56.19 & 44.76 & 44.38 \\
\hline SS2 (50\%) & 62.29 & 51.43 & 50.10 & 66.48 & 57.14 & 57.14 \\
\hline SS3(75\%) & 65.71 & 58.67 & 54.48 & 64.61 & 51.52 & 51.23 \\
\hline SS4 (100\%) & 45.71 & 32.19 & 29.71 & 44.57 & 34.48 & 33.91 \\
\hline SS5 (12.5-20\%) & 68.57 & 60.00 & 59.81 & 52.14 & 43.24 & 43.24 \\
\hline SS6 (10-15\%) & 61.71 & 52.76 & 50.48 & 48.52 & 38.66 & 37.82 \\
\hline *SS7 (100\%) & 59.62 & 46.67 & 44.76 & 61.52 & 52.38 & 51.95 \\
\hline SS8 (0\%) & - & - & - & - & - & - \\
\hline Mean & 58.90 & 50.10 & 47.89 & 56.29 & 46.03 & 45.67 \\
\hline SEM & 0.03 & 0.03 & 0.03 & 0.03 & 0.04 & 0.04 \\
\hline CD (p=0.05) & 0.08 & 0.08 & 0.08 & 0.09 & 0.11 & 0.11 \\
\hline CV (\%) & 14.06 & 17.13 & 17.87 & 17.55 & 24.13 & 24.16 \\
\hline
\end{tabular}

Note: The description of structures in first column: SS1, SS2 and SS3 were High density black polythene sheet (HDPS) shade nets; SS4 was a dark room inside the graft shed at cashew research station of Bapatla; SS5 is a trench providing partial shade of 12.5-20 percent; SS6 is a structure providing partial shade with coconut fronds; *SS7- low cost humid chamber providing only diffused light and with 100 percent shade; while SS8-was without any shade providing complete light of 100 per cent from direct sun in open air.

When Structures providing 100 percent shade is considered, it has no success more than 40 percent except in February (41.3\%) which was very less when compared to the maximum success observed under other structures for shade provision (SS1, SS2, SS3, SS5, SS6 and SS7). When compared to 100 percent shade, open conditions were better for growth and graft take with success using Bapatla technique after 20DAG. The treatments of 100 percent light under open air conditions (SS8), 100 shade in dark conditions
(SS4) inside a room of graft-shed are not recommended for SWGs produced by Bapatla or Puttur method due to their no or low per cent of success.

When interactions effects were considered, the structures SS2 in December (82.7\%) followed by SS5 in September (81.3\%) were promising (Table 10). March was the worst time for SWG and due to gradual rise of temperatures in this region of dry climate result- 
ing reduced success due to increased evapotranspiration losses from the graft surface and potted soil. Among all the structures, SS5 (trench) is the potential structure for shade with more than 60 percent success in five months out of seven months tested. This is providing a viable information necessary for graft success in Bapatla climate to avoid dry months for SWG. If there is no proper structure like this trench is built to maintain the humidity and prevailing summer temperatures, there could be no success in obtaining SWGs in cashew. Further, trench produced viable grafts in terms of success, graft height, number of leaves and leaf area when compared to other shade structures including HDPS shade nets though were providing various amounts of PAR for graft growth and enhancement. Trench was observed a success for both methods, though we chose Bapatla because of early, easy, successful and rapid production of cashew SWGs during warm summer and throughout the cropping year as observed during our investigation. These results are in line with the observations in guava SWGs [46] where mist-house ecosystem produced more success percentage (62 to $97.4 \%$ ) with maximum measures in all growth parameters followed by shade house (48 to 95\%) and mango [44] where naturally ventilated poly-house recorded significantly highest sprout length, graft height, maximum sprouted grafts $(71.27 \%)$ within 12.11 days with a maximum number of leaves (17.34) and maximum survival percentage $(67.18 \%)$ at 90 days after veneer grafting.

Trench (SS5) is simple, economical and provides a mass-multiplication facility of SWG in a short span of time and at no cost. It can become a permanent and reusable structure in all the crop seasons of the year if one adopts this structure for cashew nursery. We constructed a small trench for our experimental need, a permanent structure of trench that can hold maximum number of grafts on routine basis in Bapatla region is viable compared to the rest of the structures studied including HDPS nets. The duration and timing of ventilation, level of shade and stable temperature requirements are essentially satisfied for this structure (SS5). Further, the trench (SS5) is purely outlined both base and walls out of mud in our experiment. If this trench is constructed with low cost thermoprotective for high temperature situations as well as with water proof materials as a lining inside the walls, may help to prevent possible hazards during heavy rainfall and cyclones.

In low income situations, a farmer can adopt partial shade with coconut fronds (SS6) to full fill the shade requirements for production of cashew grafts with equal success percentage with Bapatla method. High density black polythene shade nets (SS1, SS2 and SS3) are recommended only to the regions with colder climate and with low average or mean minimum temperatures and low humidity where these nets help to modify the microclimate and enhance the sprouting and success of SWGs.

The low cost humid chamber was highly unsuccessful under Bapatla agroclimatic conditions recording less than 50 percent success in all the months except December providing us a valuable information that this structure has its adoptive advantage in cold or temperate regions and not at all good for tropical climatic conditions of southern states of coastal Andhra Pradesh where Bapatla is located.

Mortality is less in Bapatla method (39.80\%) compared to Puttur method (42.96\%) of SWG at 30 DAG and gradually decreased to 9 percent and 1-2 percent in both techniques by 60 and 90 DAG respectively (Table11). The shade structure trench (SS5) is the lead with less mortality (31.43\%) in Bapatla method followed by SS3 HDPS net (34.29\%) while SS2 was the lead structure with Puttur method recording 32.38 percent mortality. These observations indicate that graft union and healing occur within 30 days after grafting and later there is no observed failure of SWGs to grow and establish. The observed failure in some interactions of shade and some months as well as under complete shade or sun light conditions might be due to translocated incompatibility because some grafted plants were observed with leaf wilting. This failure could also to due to delayed differentiation of cambial cells in the tissues of graft joint which obstructed the flow of nutrients in the vessels and necessary hormones.

From Table 2 and 12, The success percentage was relatively high first 30 days and was more stable afterwards irrespective of the shade treatments in all the months. The structure SS5 is the best structure with more success (68.57\%) at 30 DAG followed by SS2, SS3 and SS6 in Bapatla method. In Puttur method, we observed greater success (66.48\%) under HDPS nets with 50 percent shade (SS2) followed by SS3 and SS7 at 30 DAG. The twenty-day shade treatment helped freshly prepared SWGs to heal quickly and support scion sprout and eventual growth of grafted plants. The percentages of 60 and 90 DAG were attributed to the representation of continuity in success by maintaining stability in growth. This explains us SWGs need initial shade treatment for successful grafttake and graft growth under Bapatla agroclimatic conditions.

A summary of results obtained on vegetative growth from Puttur method of grafting

In puttur method (Tables 6-9), we observed maximum success during all months except in January under SS2 and with mean maximum of 57.1 percent when compared to the remaining shade treatments. The same structure (SS2) was observed with 78.7 percent success in October. The maximum leaf area was produced in all the shade treatments, but the lead structure was SS5 producing $191.5 \mathrm{~cm} 2$ on average in all the months. September is the month that produced maximum leaf area in most of the shade structures with a key finding of observation in locally adopted structures for shade (SS5 to SS7). In Contrary, the number of leaves were less in September under all shade structures when compared to December, while graft height was maximum in SS2 in all the months. The structure SS5 was best in Bapatla region even if Puttur method is 
adopted because we observed with a maximum leaf number (12), graft height $(25.8 \mathrm{~cm})$, leaf area $(191.6 \mathrm{~cm} 2)$ though success was only 43.2 per cent at 90DAG which was less when compared to SS2 from HDPS nets with more than 50 per cent success. Thus, optimum number of leaves, age of rootstock has greater impact on the graft union, success and growth of SWGs and to efficiently utilize the available PAR and for accumulation of photosynthates.

Because our investigation was to reveal the potential method with better shade structure for Bapatla climatic conditions in comparison to Puttur method, we mostly concentrated our discussion to successful Bapatla method of SWG being proven by its potential during our investigation, though data on both methods was compared and presented throught in detail (Table 2 to 12). The numerals on growth parameters in Puttur method were more or less on par with those of Bapatla method under all shade structures. There are two major reasons observed for poorer performance in all the parameters studied in Puttur method of grafting. These are 1) Age of rootstock, as the age increases there is always a reduced success in cambial union of the graft joint. Here scion bud is precured, means a forced apical or terminal bud-stick of the mother cultivar, with a high expected percent of success in producing the new growth flush when implanted in cambial region of similar aged vigorous rootstock. This is more important factor to consider when successful and early graft union is expected. Successful matching of grafted region of scion and rootstock will lead to a maximum utilization of available nutrients from rootstock and help in early sprouting of scion bud because of tight early joining of softwood in the grafted region through the transport of hormones synthesized especially auxins. 2) Number of leaves retained on the rootstock that reduced its ability to provide hormonal signals necessary for graft union, and scion sprout on time. This led to a marginal recorded loss in success percentage when compared to Bapatla technique. The greater number of leaves might have needed more nutrients, more water for their growth on the rootstock creating a competition for growth as well as in union of the graft regions for early healing of the graft joint and subsequently to boost the scion-bud sprouting and the growth above the grafted region in Puttur method. 3) Quick and easy method: The age of the seedling used as rootstock is only 30 days in Bapatla method which will reduce waiting time to do grafting when compared to Puttur method where two-month-old seedlings were used as rootstock. We reduced the rootstock's age of the Puttur method as well to 45 days through our investigation 4) Saves resources: A 30-day period of seedling nursery maintenance for rootstock will save water, space and other necessary resources required for raising rootstocks.

Today, there are several structures designed for vegetative propagation of temperate fruit crops to know and understand the practical application of those for various climatic situations. These structures were made of polythene, and were in need of covers within a low profile enclosing larger area. The success achieved with trench in our investigation might be maintaining sufficient heat from bottom of the trench due to the plastic bag used for rais- ing SWGs as well as thick sheet covering the trench during night time with entrapped heat during day. Previous researchers from temperate regions working on vegetative propagation in various fruit crops also stated that definite shape of the polythene structure in rectangular or square were more appropriate in sealing water vapor, maintaining humidity levels using bottom heat to raise the temperature of the substrate thereby increasing evaporation and humidity in cold and enclosed conditions [47]. Thus, trench with Bapatla method of grafting is viable for high success and good graft growth. A shade requirement of 20 days is essential for good quality sprouts.

Based on the observations and results obtained from various shade structures, rootstock age and stage of grafting and a potential BPP-6 scion bud sticks, it is recommended that a future need for study of various rootstocks identified in cashew growing regions using Bapatla method of SWG using trench with partial shade and BPP- 6 as scion-bud sticks to know the influence of rootstock on scion-bud stick sprouting, graft-take, graft height, orchard establishment and to identify any dwarfing rootstock available in the Bapatla germplasm of cashew. The choice of rootstocks for study may include traits such as dwarfness, earliness in productivity, biotic and abiotic resistance, adaptability to soil or nutrient stress conditions, and suitability to high density planting if already identified for some of these traits. Among central leader, vertical axis, hybrid tree cone (HYTEC), and the slender spindle training systems (SSTS), SSTS was identified as the most productive for high-density planting using dwarfing rootstock in apple (https://content. ces.ncsu.edu). Therefore, studies on recommendations of suitable training and pruning systems for cashew trees in the first five years should be standardized before recommending the SWGs on dwarfing rootstock for new and high-density orchard establishment.

\section{Conclusion and Future Thirst}

Shade is the major means of providing optimum temperatures of growing climate, but the design and construction was always influencing the microclimate. A potential rootstock cultivar, productive scion, skillful management of shading, ventilation, optimum temperatures and high relative humidity of congenial growth environment are essential for success and for providing growth promoting substances for successful scion growth in Bapatla method of SWG in cashew at CRS, Bapatla.

For stable higher yields and early productivity, dwarfing rootstocks of cashew must be identified and thoroughly evaluated to accommodate the maximum grafted tree population per acre in newly established orchards in upcoming years. Some improvements were made by testing hydraulic and tensile strength through the graft joint for successful graft union in a non-destructive way. As of now only one dwarf cashew cultivar (Anacardium occidentale $\mathrm{L}$ var. nanum) available with various clones developed for earliness [48]. Studies on hormonal application on the graft joint and testing the hydraulic conductance to understand the waterflow continuum also will help to maximize the SWG production in cashew as it 
might leave some clues for induction of dwarfness in rootstocks. These necessary research inputs for high density planting in coming years will help to improve cashew by protecting from wind damage and heavy flower drop.

Biochemical analysis of softwood region in grafted joint for the synthesis of compounds such as carbohydrates, lipids, starch, cellulose, hemicellulose, lignin etc., may help to reveal the underlying reasons for the successful graft take and quick healing by resisting separation during graft union in Bapatla method (35 days old rootstock of BPP-5 retaining two leaves). This analysis might also reveal some negative effects of compounds such as polyphenols and flavanols produced in response to stress due to wounding caused while grafting. This will help to understand the reasons for the requirement of initial 20-day period of shade to the prepared softwood grafts and the factors that were down regulated by provision of shade.

Continuous plasmodesmata occurs in well matched vascular regions when parenchymatous tissue of same kind from both rootstock and scion were aligned like pith with pith and cortex with cortex which initiates early cell to cell communication between dividing cells. A compatible graft union quickly initiates a callus bridge leading wound repair xylem and phloem and cambial cell differentiation. If the vessels are not connected graft trees may result in a s-shaped curve. Vascular continuity allows transport of water and nutrient absorbed in the roots to the leaves where photosynthesis converts carbon dioxide to sugars which can be transported back to roots and other plant parts. During the disturbance of this normal flow, auxins were primary hormones responsible for xylem (high auxin) and phloem (low auxin) differentiation and increased vessel number leading to success.

When the genetic basis for dwarfism in peach was studied, the sequence of $d w$ revealed allele PpeGID1c in vegetative growth and elongation, whereas GID1b to regulate gibberellic acid perception in reproductive organs and suggested that modification of GID1c expression may control tree size without impairing fruit development [49]. Thus, by managing shade and light provisions we might understand the hormonal basis as well as the expression of genes favoring low graft height because we observed extreme variations in graft height under certain shade structures.

\section{Acknowledgement}

Authors like to acknowledge the technician who helped preparing SWGs on monthly basis for each treatment. Because this technician is like an automated machine in producing softwood grafts with quality in cashew without his help, we might have not been able to conduct this huge experiment. Sincere thanks to Pradeep Kumar Sripathi, and late Mr.Narina Kondala Rao garu, Father of Satya SS Narina for providing new vehicle and money to do the experimental investigation on time at our research farm. Author Satya Narina extended unconditional support received from Mr.
Borra Shiridi Sai Baba and Mrs. Sarada, the adopted parents of Satya SS Narina and Professor, Dr. C Ravi Sankar during the final stage of thesis drafting period.

\section{Bibliography}

1. Gaur NVS. "Comparative evaluation of mango propagation methods". Punjab Horticultural Journal 24 (1984): 1-6.

2. Nagabhushanam S. "Vegetative propagation technique in the cashew". Paper presentation in the seminar on cashew research and development in the coastal region 7-8 (1985).

3. Purushottam K and Narasimha Rao. "Propagation of tamarind by veneer and soft-wood grafting". South Indian Horticulture 38.4 (1990): 225.

4. Seshadri KV and Rao Rama Rao. "Modified method of epicotyl grafting in cashew for commercial propagation”. Indian Journal Cashew 17.4 (1987): 11-13.

5. Swamy KRM. "Soft-wood grafting and nursery management in cashew". Technical Bulletin NRCC, Putture P (1993): 1-11.

6. Sawke DP., et al. "Soft-wood grafting. A sure technique of clonal propagation in cashew". Indian Cashew Journal 17.1 (1985): $17-18$.

7. Khan MM., et al. "Rejuvenation of old cashew trees by top working”. Indian Cashew Journal 17.3 (1985): 9-25.

8. Pushpalatha PB., et al. "A study on the propagation ability of cashew types to different methods of vegetative propagation". The Cashew 4.4 (1990): 16-17.

9. Nawale RN and Salvi MJ. "Studies on vegetative propagation of cashew nut". The Cashew 4.2 (1990): 2-5.

10. Adams SW. "The effect of rootstock, scion, grafting method and plant growth regulators on flexural strength and hydraulic resistance of apple". Thesis for MS in plant science submitted to Utah University, Logan Utah. (2016): 166.

11. Cookson SJ., et al. "Graft union formation in grapevine induces transcriptome changes related to cell wall modification, wounding, hormone signalling and secondary metabolism". Journal of Experimental Botany 64.10 (2013): 2997-3008.

12. Ratan J. "Studies on stone grafting in mango". South Indian Horticulture 35.3 (1987): 192-198.

13. Gowda BJ and Melanta KR. "A note on epicotyle grafting of cashew". Current Research UAS, Bangalore 20.6 (1991): 119120.

14. Kulkarni UA and Kulwal LV. "Further studies on in situ grafting and growth behaviour of some varieties of mango under Akola conditions. Thesis abstracts". Silver Jubilee (1989): 1969-1994. 
15. Hartman HT and Kester DE. "Plant propagation-principles and practices". Third edition published by Printice Hall of India Private Limited, New Delhi 110001 (1978).

16. Singh NP., et al. "Seasonal effect on success in different methods of mango propagation". Indian Journal of Horticulture 36.2 (1979): 134-139.

17. Srivatsava RP. "Propagation of mango by newer techniques". Acta Horticulture 231 (1989): 266-267.

18. Venkata Rao P and Nagabhushanam S. "Further studies on propagation trials in cashew". Indian Cashew Journal 13.2 (1982): 5-7.

19. Swamy KRM., et al. "Evaluation of success in soft-wood grafting cashew with weather parameters". South Indian Horticulture 38.6 (1990): 297-300.

20. Pampanna Y., et al. "Effect of season on the success of soft-ood grafting in sapota (Cv. Kalipatti)". South Indian Horticulture 42.5 (1994): 303-308.

21. Sarada C., et al. "Effect of different root stocks and time of grafting on the graft-take and initial growth in cashew". Cashew Bulletin 29.9 (1992): 18-20.

22. Patil JD., et al. "Studies on wedge grafting in mango". Punjab Horticulture Journal 23.1 (1983): 29-33.

23. Patil BM and Amin RS. "Investigations into the best period for grafting of mango insitu". South India Horticulture 29.1 (1981): 90-94.

24. Nageswara Rao MB., et al. "Effect of some propagation structures on rooting of stem cuttings of cashew". Indian cashew Journal 20.1 (1988): 17-20.

25. Maxwell Norman P and Lyons CG. "A technique for propagating container grown citrus on sour orange root stock in texas". Hort Science 14.1 (1979): 56-57.

26. Seneviratne KGS., et al. "Influence of shade on rooting and growth of black pepper (Piper nigrum L.) propagules". Journal of Plantation Crops 13.1 (1985): 41-43.

27. Seneviratne KGS., et al. "Influence of shade on rooting and growth of black pepper (piper nigrum L.) propagules". Journal of Plantation Crops (1987).

28. Terranova G and Caruso A. "The effect of environment and type of container on citrus seedling development. Annalidell Istituto-Sperimentale per-1". Agrumiculture (1988): 171-211.

29. Uzquiano MC. "An alternative to the method presently used when grafting young avocado trees". Proceedings of the Florida State Horticultural Society 87 (1974): 345-347.
30. Satya syamala sundari Narina., et al. "Effect of graft take, potential rootstocks and a comaprtive study on grafting techniques in cashew (Anacardium occidentale L.)". Acta scientific Nutritional Health 4.2 (2020): 01-09.

31. Sundari NSS and MLN Reddy. "Influence of shade on success and growth of softwood grafts in cashew". Andhra Agricultural Journal 50 (2003): 83-85.

32. Sundari NSS., et al. "Effect of time and shade on softwood grafting in cashew nut (Anacardium occindentale L.), National seminar on new horizons in production and post-harvest management of tropical and subtropical fruits 1998 (1999).

33. Shylaja MR. Standardization of the technique of stone grafting in cashew (Anacardium occidentale $\mathrm{L}$ ) and management practices for field establishment. Thesis submitted to Karnataka Agricultural University, Vellanikata for the partial fulfilment of M.Sc. (Ag.) (1983).

34. Pushpalatha PB., et al. "Studies on variable influencing success in soft-wood grafting in cashew". The Cashew 5.3 (1991): 7-9.

35. Mohan Kumar B and Prabakaran PV. "Determination of leaf area in pepper (Piper nigrum L) using linear measurement". Indian Coca Areaca-nut and Spices Journal 4.1 (1980): 1-3.

36. Panse VG and Sukhatme PV. "Statistical methods for agricultural workers ICAR New Delhi”. (1978): 152-157.

37. Kadam SG., et al. "Studies on in situ soft-wood grafting in cashew (Anacardium occidentale L)". Cashew 9.2 (1995): 8-11.

38. Jose M., et al. "Standardization of vegetative propagation technique in Jack (Artocarpus heterophyllus Lam.)". Punjab Horticulture Journal 31.1-4 (1991): 145-147.

39. Senanayake YDA and Kirti Singhe JP. "Effect of shade and irrigation on black pepper (Piper nigrum L) cuttings". Journal of Plantation Crops 11.2 (1983): 105-108.

40. Panicker P and Deasi AG. "Effect of age of scion mother tree, different flushes of rootstock and insitu grafting on success and growth of softwood grafts of Alphonso mango". Progressive Horticulture 21.1-2 (1989): 141-144.

41. Anonymous. "Annual Report 1993-94". CRS, Bapatla (1994).

42. Saito $\mathrm{T}$ and Ito H. "Studies on growth and fruiting in tomato. Effect of early environmental conditions and cultural treatments on the morphological and physiological development of flower and flower drop. The effect of night temperature, light intensity and the fertility of the bedding soil". Journal of Japan Society of Horticultural Science 36 (1967): 195-205. 
43. Sankar Reddy T 1983 Studies on flower production and fruit set in green gram (Vigna radiata var aureus) as influenced by soil moisture and shading. M.Sc., (Ag). Thesis submitted to APAU, Hyderabad.

44. Sivudu BV., et al. "Effect of structural conditions on veneer grafting success and survival of mango grafts (mangifera indica cv.Banganpalli)". Plant Archives 14.1 (2014): 71-75.

45. Seshadri KV and Rao Rama Rao. "Effect of age of rootstock and pre-treating scion on the success of soft-wood grafting in cashew". South Indian Horticulture 34.4 (1986): 255-257.

46. Manga B., et al. "Studies on effect of propagation environment for softwood grafting in guava (psidium gujava L) cv Sardar". International Journal of Current Microbiology and Applied Sciences 6.6 (2017): 2779-2783.

47. Brian E Humphrey. Textbook: "The Bench Grafters Handbook: Principles and Practices". (2019): 637.

48. Donadio LC., et al. "Dwarfing -canopy and rootstock cultivars for fruit trees". Revista Brasileira de Fruticultura Jaboticabal 41.3 (2018): 12.

49. Hollender CA., et al. "A brachytic dwarfism trait (dw) in peach trees is caused by a nonsense mutation within the gibberellic acid receptor PpeGID1c". New Phytologist 210 (2016): 227239.

\section{Assets from publication with us}

- Prompt Acknowledgement after receiving the article

- Thorough Double blinded peer review

- Rapid Publication

- Issue of Publication Certificate

- High visibility of your Published work

Website: https://www.actascientific.com/

Submit Article: https://www.actascientific.com/submission.php Email us: editor@actascientific.com

Contact us: +91 9182824667 